\title{
Amateurs meet professionals: theatrical activities in late sixteenth-century Italian Academies
}

Book or Report Section

Accepted Version

Sampson, L. (2015) Amateurs meet professionals: theatrical activities in late sixteenth-century Italian Academies. In: Earle, T. F. and Fouto, C. (eds.) The Reinvention of Theatre in Sixteenth-Century Europe: Traditions, Texts and Performance. Legenda, Oxford, pp. 187-218. ISBN 9781907975769 Available at http://centaur.reading.ac.uk/39333/

It is advisable to refer to the publisher's version if you intend to cite from the work. See Guidance on citing.

Publisher: Legenda

All outputs in CentAUR are protected by Intellectual Property Rights law, including copyright law. Copyright and IPR is retained by the creators or other copyright holders. Terms and conditions for use of this material are defined in 
the End User Agreement.

www.reading.ac.uk/centaur

\section{CentAUR}

Central Archive at the University of Reading

Reading's research outputs online 


\title{
Amateurs Meet Professionals: Theatrical Activities in LateSixteenth-Century Italian Academies
}

\author{
Lisa Sampson
}

University of Reading

\begin{abstract}
Lo studio è necessario per saper, occorrendo, trattare di tutte le materie non solo in comedia, ma nelle Academie: poiché pure vi sono Academie illustrissime che, per testimonio che i comedianti che fan[n]o l'arte loro come si conviene non sono indegni d'essere ammessi nelle loro adunanze, hanno accresciuto il numero de gli academici accettando e uomini e donne che ordinariamente comparivano in iscena, come avenne in Pavia alla signora Isabella Andreini, ed in Firenze a suo figlio, che l'una negl'Intenti e l'altro ne' Spensierati, furono accolti [...].1

[Study is required to be able to discuss, if necessary, not only all subjects in comic theatre but also in Academies: for there are even some most illustrious Academies which have increased their membership by accepting men and women who have regularly appeared on stage, as is evident from the fact that those actors who practise their art as they should are considered worthy of being admitted to their gatherings. This happened in Pavia to Madame Isabella Andreini, and in Florence to her son [Giovan Battista], she being admitted to 'The Academy of the Intent' [Intenti] and he to 'The Academy of the Carefree' [Spensierati].]
\end{abstract}

In 1623, the working actor Domenico Bruni presented membership of a literary academy as a clear sign of the great recognition awarded to some of the leading actors of his age, and mentions as examples the legendary actress and writer Isabella Andreini (in 1601) and her actor-dramatist son, Giovan Battista (in 1604). Bruni even cites such membership alongside the imperial honours awarded to another prominent actor, Pietro Maria Cecchini. Five years later, yet another learned actor, Nicolò Barbieri, would similarly consider academic affiliation as the acme of an actor's career.2 For Bruni, such an honour clearly illustrated the dignity that he was claiming for his profession (or arte), which he argued was based not only on art, that is, study and learning, but also natural talent which could not necessarily be learned even by intellectuals. To put this view into perspective, only a few decades earlier it would have been unimaginable for most learned academies, institutions founded by intellectuals especially from the 1540s for virtuous education and learned recreation, to have admitted what were typically considered 'unlettered', itinerant and immoral, mercenary actors (zanni) into their hallowed throng. As Richard Andrews observes, despite some aspects of mutual influence, the midcentury in Italy witnessed an increasing separation 'in which the professional performers of farce and the gentlemanly composers of literary comedy went their separate ways'.3 However, with the more or less coetaneous appearance of formally constituted companies of actors, first documented in Padua in 1545 in the case of the 'fraternal compagnia' of Ser Maphio detto Zanini, this split seems to have intensified while becoming more problematic to sustain.4

Something of the sense of intellectual opposition towards - and fascination for - such professional groups is captured in the satirical verse of the unorthodox Florentine poet and dramatist, Anton Francesco Grazzini (1504-1584), himself a member of the Accademia degli Umidi, the more unruly predecessor of the Medici-sponsored Accademia Fiorentina: 


\author{
Hanno i poeti questa volta dato \\ del cul, come si dice, in sul pietrone, \\ poi che il nuovo salone sverginato \\ stato è da Zanni per lor guiderdone, \\ onde delle commedie hanno acquistato \\ la Gloria tutta e la riputazione: \\ così da i Zanni vinti e superati \\ possono ire a impiccarsi i letterati.
}

(Le rime burlesche, c. 1552)5

[This time the poets have fallen / on their backsides on the floor, one might say, / as the new hall has been sullied / by zanni [comic actors] for their profit; / their comedies have gained them / all the glory and reputation: / now the literati, beaten and outdone by the zanni, /can go hang themselves.]

While it is unclear to which performance or hall Grazzini (known as 'Il Lasca') is referring here, there is no mistaking the disruptive effect of the performances of these troupes which had rapidly became popular in northern and central Italy. As this academician facetiously suggests, such companies presented a competitive challenge to the groups of serious 'poets' or literati which also began to be formally constituted around the same time, and who likewise pursued public acclaim and glory, among other things in the field of theatre. Grazzini's lively and contradictory account of arte performances in his various festive poems suggest that these presented a popular alternative to the scripted humanist plays written and staged by academies, which were typically characterized by long set-piece descriptions and careful attention to the classical ideals of verisimilitude and decorum. Whether performed by dignified professionals or street players, 'the new theatre provides a richer signifying system, complementing voice with actions, manners, and gestures'.6

So does the fact that the Andreini, mother and son, were members of an academy by the early 1600s indicate altered and improved relations between these two kinds of 'institutions' as far as theatrical production was concerned? Or at least an opening of some academies towards some select comici in the later sixteenth century? If so, what kind of social and cultural forces can explain this? And what pressures did the opening of membership in the case of the Intenti or Spensierati academies, respectively of Pavia and Florence, bring to bear on the institutions themselves and their theatrical production?

This chapter can only begin to touch upon the broader questions surrounding the still obscure and complex relationship between the new professional theatrical companies and the Italian literary academies. This is due in part to the difficulty in providing an overview of 'academic theatre' in the period, given the great diversity of academies in their typology and activities across the peninsula. There is a shortage of systematic, in-depth analysis of this phenomenon, especially compared to the comprehensive scholarly documentation of the comparatively sparse surviving evidence for arte practices in the early decades of its existence. Nonetheless, scholarship has begun to touch upon specific relations between actors and academies.7 Research on late sixteenth-century Italian academy theatre, moreover, is often coloured by a prevailing negative view which holds that dramatic practices were informed by pettifogging literary debate and archaizing tastes. Academies should, however, properly be regarded as forming a third, somewhat hybrid and culturally vibrant sphere for the production of theatre in the late sixteenth- and early seventeenth-century Italy, alongside the traditional sphere of the princely courts, and the newly emerging professional marketplace. This would 
explain why comici were aware of the need to engage with these flourishing and predominantly secular institutions, especially in the transition period between c.1585, when court-sponsored theatre became less frequent, and 1637 when the foundation of professional opera theatres in Venice began to provide a more steady income stream for actors.

\section{Academies vs comici dell'arte: Antagonism or Overlap?}

During this time, academies could offer economic or practical benefits as well as the social validation that many learned actors like Bruni sought. Less clear, though, is why an academy would admit a professional actor to their sodality. As Grazzini's verse suggests, academies and their members typically liked to present themselves in their theatrical practices as distinctly superior, and even antagonistic, to professional troupes - now known by the eighteenthcentury term of commedia dell'arte.8 Arte actors in the sixteenth century were often disparagingly termed by literati as comici della gazzetta ('tuppenny actors', referring to a Venetian low value coin). Battista Guarini, the author of the Pastor fido (first printed 1589), famously described them as 'sordid and mercenary people', who have profaned comedy.9 Like his colleague, Angelo Ingegneri, in his treatise on theatre (Della poesia rappresentativa, 1598), Guarini does however distinguish between corrupting practitioners of this potentially noble art, and virtuous thespians - a distinction that actors themselves would soon apply. The 'othering' of professional comici was of course sanctioned by religious discourse and political legislation. It must also reflect a sense of competition on the part of aristocratic intellectuals and, as Roberto Tessari suggests, represent a defensive response on their part to what they perceived to be a contaminating act of theft perpetrated against them by the 'ignoble plebeians'.10

Such distinctions between traditions have traditionally been perpetuated in criticism. As mentioned, academies are often viewed as favouring humanist-inspired, literary, and antiquarian forms of theatre (as epitomized by the first academy theatre in Vicenza, the Teatro Olimpico), typically influenced by critical (mostly Aristotelian) theoretical considerations, and cultivated predominantly by amateurs. Professional companies, on the other hand, are considered to be based broadly on popular, oral culture, using freer 'modern', improvised forms, as well as fixed characters or 'masks' and dialect. However, recent scholarship has shown that such ideas require careful nuancing. Studies of commedia dell'arte have demonstrated extensively that there was much productive cross-fertilization between this art-form and learned culture both in terms of performance practices, content, and rhetorical style. From the 1570 s, numerous leading arte practitioners began to imitate, adapt and challenge more official 'literary' forms and ideas through their dramatic, literary and theoretical writings. On the other hand, the academies could be laboratories for changing conceptions of dramatic genre and theatre design: the Olimpici Academy of Vicenza developed new technical devices for lighting, while the Alterati Academy and the Camerata de' Bardi of Florence were instrumental in pioneering the explicitly modern dramatic genre of melodramma (opera). The Intronati Academy of Siena has been studied especially for its performances of trend-setting, collectively written plays.11

These two kinds of 'microsocieties', each relatively closed and self-regulated in their distinct ways - and for different reasons - may then have sought ostensibly to promote different kinds of theatrical experience, but they also increasingly came into contact (at least in the case of the leading companies) within the context of Court theatre during the later sixteenth century.12 Aristocratic patrons made use of both academies and professional troupes to deliver the most spectacular and innovative theatrical events possible for important political occasions, doubtless engendering both rivalry and emulation among the different kinds of theatre producers as they converged. Notably, at the much lauded 1589 Medici wedding celebrations in Florence, an academic comedy (La Pellegrina [The Lady Pilgrim]) by Girolamo Bargagli, a member of the Intronati who had died in 1586, was staged by young amateurs from the same 
academy. The lavish and innovative intermedi which were interspersed between the acts of the play, probably against the wishes of the academicians, were designed by the leading Florentine nobleman and academician Count Giovanni de' Bardi as well as others, but executed by a variety of leading professionals in different fields. These mythological interludes were repeated several times during the festivities and probably accompanied the virtuoso performances of first Vittoria Piissimi with the Gelosi troupe in La Cingana [The Gypsy] (perhaps based on a comedy by Gigio Giancarli) and then, a few days later, of her rival leading lady, Isabella Andreini, in $L a$ Pazzia d'Isabella [The Madness of Isabella]. For practical reasons, all these performances were held in the same recently remodelled Medici Theatre in the Uffizi.13

While such aspects of convergence and rivalry especially in courtly contexts have received great attention from historians of theatre and especially of commedia dell'arte, research into specific cases of professional actors approaching or belonging to formal 'literary' academies before and around 1600 has been more limited. Why and how were they accepted? And what form did their association take? Mostly, scholars are content simply to repeat uncritically the assertion that actors (especially Isabella Andreini) were admitted in this period.14 Studies documenting links between (and even borrowings from) actors and celebrated playwrights of the time, like Battista Guarini and Gabriello Chiabrera, who belonged to numerous academies as well as informal aristocratic circles, provide a context for this kind of investigation. So too does the evidence of professional artists and musicians joining literary circles and more experimental academies, especially in Rome, Florence, Siena, and Milan from around 1600.15 Nonetheless, unlike their fellow virtuosi musicians and even artists, actors in this period - and indeed for long after - presented a more oblique relationship with the liberal arts generally cultivated in academies (notably with rhetoric through the arts of memory, oratory, and invention), and faced particular prejudice because of their unconventional and apparently immoral, even irreligious, lifestyle.

This chapter aims to add some further evidence for interactions between early professional actors and academies, which will help to nuance Bruni's assertion quoted above. It will also question why, and which, academies accepted actors as members. First, the academic context will be introduced, then there will be a brief examination of some specific cases of interactions between the actors Adriano Valerini and Isabella Andreini with academies in Northern Italy around the end of the sixteenth century. Closing observations on Giovan Battista Andreini will signal further developments in the next century.

\section{Theatrical Practices in Sixteenth-century Italian Academies}

From the mid-sixteenth century secular theatre was one of the specific activities most cultivated by academies, which were commonly at this time interdisciplinary in character, though marked by a strong penchant for ritual and spectacle. Indeed, theatrical activities formed the major concern of two of the earliest academies formed, the above mentioned Intronati of Siena (1525) and the somewhat anomalous Congrega dei Rozzi (1531), as well as of others such as the Olimpici of Vicenza (1555) and the Innominati of Parma (1574). These institutions to different extents led the way in innovating dramaturgical and technical practices, in addition to theatrebuilding during the later sixteenth century. Such high profile examples were merely the tip of the iceberg: Amedeo Quondam's important survey essay on Italian academies calculates that $4.2 \%$ of the 2,000 or so academies listed in Michele Maylender's encyclopedia (itself a somewhat problematic source) had a special interest in theatre in the sixteenth century. This interest remained at about the same level in the seventeenth century (4.3\%), rising to $6.6 \%$ in the eighteenth century.16 In some centres this specialization was more marked. In Florence from the sixteenth to the eighteenth centuries it has been calculated that about 42\% (45 of 106 
documented academies) cultivated theatre in a sustained fashion, though a large proportion of these fall in the later part of the period surveyed.17

Such cultivation of theatre was in some cases a hangover from earlier more socially mixed groups, including 'bourgeois' confraternities, and festive societies like the Compagnia della Cazzuola of Florence, which included the freelance actor Domenico Barlacchia.18 For more exclusive academies, there must have been some continuity with the earlier sixteenth-century practices of festive companies of young patrician elites like the Venetian compagnie della calza [companies of the hose], upon whose constitutions the notarized contract of the first professional group was based.19 These compagnie were active until 1565, first performing and then patronizing comedies. This explains why public, dramatic spectacles were usually staged by academies for occasional or festive events (feste) before distinguished invited audiences and, importantly, why they were not commercially motivated.20

In hosting or staging public performances academies typically sought to exploit the power of spectacle to gain prestige and honour for their institution, reflected glory for their members and city, as well as potentially to attract political patronage and public recognition. For this reason, if the occasion demanded it, they would recruit high-profile professional musicians, artists and scenographers, following the practice of courtly sponsors. The dramatic texts selected for performances could be by academy members or outsiders, though in either case they were subjected to close collective scrutiny usually by censors (censori), who were specially appointed. (One wonders whether improvised comedies with arte style 'masks', widely documented from the 1620s, were practised much in Italian academy contexts before 1600, as they had been for the famous 1568 performance at the Munich Court in Bavaria.21) As at the 1589 La Pellegrina performance in Florence, however, the actors were normally amateurs and male in the sixteenth century, following earlier and continuing courtly practices.22 Nonetheless, as we shall see, there is some rare evidence of women on stage in plays put on by academies in the late sixteenthcentury academy.

By this time, however, the distinction between amateur and professional was complicated by the presence of a few highly specialized, semi-professional actors. In northern Italy they were associated particularly with Ferrara, rather than Florence and Mantua, the more remunerative centres for arte performances. As Alessandro Marcigliano has documented, actors of this kind like Giovan Battista Verato were highly valued for their practical skills within courtly and academic spheres, and carefully presented as virtuoso amateurs.23 The specialized team of amateur actors led by the literato and actor-dramatist 'Ruzante' (Angelo Beolco, d. 1542), a protégé of the patrician Alvise Cornaro in Padua who at one time worked with Ariosto, also provides a transitional model for the evolution between amateur and professional theatrical groups. 24

The performance in 1585 of Orsatto Giustinian's translation of Sophocles's Oedipus Rex to inaugurate the magnificent theatre of the Accademia Olimpica of Vicenza provides a welldocumented example of both traditional and innovative aspects of academic theatre. Innovations abounded in the theatre itself, designed by Andrea Palladio with additions by Vincenzo Scamozzi, in the lighting technologies by Antonio Pasi, the music by the organist of St Mark's Venice, Andrea Gabrieli, and the splendid costumes probably designed by the artistmember Giambattista Maganza. By contrast, the director, the Venetian literato Angelo Ingegneri, was a highly skilled amateur, as were (it appears) the actors taking the speaking roles, thus allowing the academy to circumvent Venetian theatre legislation which pertained to professionals.25 The eight speaking parts were played by dramatists and writers as well as (initially) university professors from the Veneto area. There was also a chorus of fifteen, and nearly one hundred other non-speaking parts on stage, including, unusually, young women and children ('putti'). Surviving eye-witness accounts report favourably on the staging aspects. However, of the actors, Giacomo Dolfin singled out for praise only the experienced semi- 
professional, Giovan Battista Verato, who played Tiresias, the priest of Apollo, and, unusually for a public academy performance, his daughter, who played Jocasta. Both had been brought to Vicenza by their sponsor, Battista Guarini. Dolfin praises the girl's control of voice and gesture, but especially her extremely moving performance in the recognition scene. However, Antonio Riccoboni in his more critical account found it to be lacking 'affetto' or emotional power; and criticized the inappropriate casting of this 'giovinetta, assai bella putta' [very pretty young girl] as Oedipus's older consort (and mother).26 Others commended the off-stage singing and playing by two sisters, Elisabetta and Lucia Pellizzari, who served the academy as salaried musicians (1582-87), though not in the capacity of full members.27 Two further very young girls appeared in the esodo (as Antigone and Ismene).

This performance thus provides unusually early evidence of women performing on stage for an official, public academy event, at a time of significant restrictions on theatre in the Veneto, even for noble academies. A continuum may in this respect be seen with the Olimpici's private musical performances, for example by the professional Maddalena Casulana in 1583 and perhaps by the noblewoman poet Maddalena Campiglia. Such entertainment undoubtedly reflects contemporary courtly practices, especially in Ferrara with the celebrated musica secreta performed in private first by skilled amateurs and then by professionals. It also looks forward to a greater inclusion in academies, from the turn of the seventeenth century, of virtuoso female poet-musician-performers, sometimes as full members, despite the usual formal constitution of academies as male-only preserves. Virginia Cox has gathered significant new evidence in this respect. An important example is the exceptional intellectual and poet Margherita Sarocchi's active participation in academy debates and literary activities in Rome; first with the Umoristi, founded for a performance in 1600, then as a founder of its offshoot, the Ordinati Academy (1608).28 Similar involvement may perhaps be hypothesized for the noble Sienese musicianpoet Ippolita Benigni Manfredi, who became a member of the Affidati of Pavia, the Insensati of Perugia, and perhaps the Informi of Ravenna (by 1609) - as well as for the actress Isabella Andreini.

The question of female performance within academies - of music, poetry and drama - still requires further examination, but could present an important motive for contacts between the worlds of the academies and commedia dell'arte. As is well known, commedia dell'arte practices changed significantly with the appearance of actresses (documented in Italy from 1564) who, together with a number of learned actors, could in the mask of the innamorata play more socially elevated roles and engage with 'serious' and moral genres, while often performing as singers. This created a more hybrid form of theatre, mixing higher with the traditional lower registers.29 At around the same time some actors and their companies began to gain wider recognition in Italian princely courts and the royal Court of France. From the 1570s a few actors also began to venture into print to seek commercial success, fame and honour ('symbolic capital') for themselves, and increasingly sought to defend and commemorate their profession.30 In this way, higher-level, educated actors began to encroach on the theatrical preserve of letterati and academies, competing for the same patronage and print markets. This tendency towards upward social mobility and transcendence of the material aspects of the art must also explain the fantastic names and emblems that some of the most distinguished commedia dell'arte companies took on, which are evocative of academies, starting with 'I Gelosi' [The Jealous], who adopted the emblem of the Janus face.31 For this reason, it is sometimes difficult to distinguish between these groups where the only surviving documentation relates to theatrical performances.

Despite the efforts by academies with theatrical interests to distinguish themselves in name and style from professional companies, there was still some blurring of the boundaries. Naturally, if academies themselves took on the production of drama, they were obliged to adopt a corporate approach and could over time assume specialized 'roles' as in professional troupes. The Intronati Academy of Siena also appear to have composed their plays collaboratively under 
a collective name in the mid-sixteenth century, and in ways suggesting the modular approach of the commedia dell'arte.32 Furthermore, as we have seen, various skilled amateur directors and actors like their professional counterparts were peripatetic, including Battista Guarini, Angelo Ingegneri, and Luigi Groto, who operated across courtly and academic venues in northern Italy (like their courtly predecessors) and worked closely with their preferred musicians, engineers and architects - as well as actors.33 Such collaboration by academies and their members with professionals of this kind could stimulate innovations especially in scenography and theatre design, which allowed them (as in the case of the Olimpici of Vicenza) to compete with princely patrons, and distinguished their productions from the public ones of itinerant comici. However, an academician's openness to effective stage practices and appeal to modern sensibilities could, if extended to dramaturgy, result in outcomes that to other academic critics smacked pejoratively of arte practices. Notably, the Paduan university professor Giason Denores publicly argued in 1586, and again in 1590, that Guarini's tragicomedy Pastor fido not only lacked the novelty the dramatist claimed for his work but, worse still, it imitated arte productions. The vehemence with which in 1593 the dramatist (presumably) - under the academic pseudonym 'L'Attizzato Ferrarese' - denies any such hybrid and low-brow precedent in his erudite play, and defends the nobility of the actor Verato (who supposedly penned the first defence of the play in 1588), testifies to the contested nature of amateur 'academic' status in this case. 34

Given the blurring between 'academy' and 'professional' theatrical practices and dramaturgy, it is striking how little concrete evidence there is of actual contacts between these milieux up to at least 1600, when the Roman Umoristi academy was founded and began to open up to singers, semi-professional actors, and women.35 If one sets aside the unusual example of the Intronati of Siena, which more than others straddles the divide between amateur and professional, it would seem that by 1604 the only securely documented instance of a professional actor becoming a full member of a literary academy is Isabella Andreini. This actress joined the Intenti academy of Pavia in 1601, with the nickname 'L'Accesa' [The Enflamed], as attested by the local contemporary historian and poet laureate, Antonio Maria Spelta. After Andreini's death, the editors of her literary works and pastoral play (Mirtilla) also emblazoned her academic identity on printed editions. Notably, a cluster of compositions by the Intenti are placed prominently and highlighted typographically in the second part of the 1605 edition of Isabella Andreini's Rime.36

The evidence for her son Giovan Battista's membership of the still little known Accademia degli Spensierati of Florence (documented in print publications from 1600), stated as fact by Domenico Bruni and others, is a little less conclusive. Giovan Battista, a Florentine citizen despite his itinerant existence, and educated at Bologna university, clearly demonstrates his connections with this academy in his early print publications. As Fabrizio Fiaschini has detailed, four printed works (dated between 1604 and 1606), including his tragedy Florinda (1606), refer to the academy and its members in their dedicatory letters, through internal references, the inclusion of verse by members, and other circumstantial links.37 Importantly, a portrait engraving preceding the text of Florinda pictures the actor wearing a medal with a symbol that evokes the emblem of the academy, which was possibly given to him in recognition of his services or merit. However, the medal does not fully reproduce the academy emblem (there is no motto for example). In addition, unlike in the case of other dramatist members of this academy (including Vincenzo Panciatichi, Francesco Vinta and Giovanni Soranza), there is no mention of Andreini's academic nickname in the linked publications. After 1606, Andreini's publications no longer mention this association, though the academy was still publishing theatrical and other literary works after this time. This may reflect the actor's physical distance from the academy and a consequent break in connections, perhaps prompted by the academy itself. Though, as has been suggested, it may also indicate Andreini's sense that he no longer needed academic validation of his success. 38

Earlier on, the supposed association between the Veronese actor, Bernardino Lombardi, and the Rinnovati academy of Ferrara, on the basis of a play published in 1579 under an academic 
pseudonym, is now thought to originate from the actor's own attempt at plagiarism.39 Yet there is some evidence of connections from the 1560s between arte actors and academies that specialized in the visual arts, because of their mutual interest in hybrid and even anti-literary cultural forms, in impersonation, and in the expression of the 'affects'. As Elena Tamburini has shown, Simone Panzanini of Bologna, famous for taking the Bergamasque porter role in the Gelosi company, among others from the group, had connections with the more socially and culturally heterogeneous and marginal Accademia della Val di Blenio (near Milan). This Academy was founded in 1560 and presided over for many years by the painter and theorist Giovanni Paolo Lomazzo.40 By 1585, Isabella Andreini also became close to some leading members of this and other more 'serious' Milanese academies, including the important cultural operator and poet Gherardo Borgogni, a member of the Inquieti academy of Milan and the Intenti of nearby Pavia.

However, printed works by actors often exude a sense of separateness from more official academic circles. Like many novice writers, some explicitly express fear of hostile criticism from academicians versed in the art of poetics rather than performance. In the manner of Grazzini, various cultured professional actor-writers also exploited the opposition in polemic and parodic vein. For example, the popular collection of facetious letters by Cesare Rao (L'argute e facete lettere, first printed in Brescia, 1562) presents much academic satire, through pillorying pedants, mocking academic-style conclusioni and orations, and even a paradoxical address from the 'Academy of the Zanni' to the 'Academy of the Ignorant' (Accademici Ignoranti).41 Rao is addressed in these both as the 'presidente' and 'Lo Svegliato' [The Awakened] of the Academia Peregrina, which coupled with a mention of Anton Francesco Doni in the address just mentioned, apparently suggests his connection to the fictitious academy invented by this poligrafo. These letters in fact uniquely turn out to plagiarize Doni's - an act that Rao would not, Giorgio Masi argues, have dared to contemplate for any other academy.42 A contemporary Sicilian comico Vincenzo Belando ('il Cataldo'), author of Lettere facete e ghiribizzose (Paris, 1588) similarly signs himself in one as 'el Dottor incognito Accademic Balord' [The Unknown Doctor, the Idiot Academician].43 As late as 1655, Bartolomeo Bocchino or Zan Muzzina's works are accompanied by sonnets by such unlikely comici academicians as Zan Gurgola, Academico Frullato [The Whirled up Academician] and Zan Scaramuzza, Academico Sdruciolato [The Slipped over Academician].44

It seems then that more elite and formal academies tried to maintain an outward segregation of their theatrical practices from those of the professional comici in this formative period before the opening of Venetian opera theatres in 1637. They did this through controlling access to membership and their performance spaces, and by differentiating performance practices and actors involved. How far then did these theatrical economies - professional vs 'serious' literary academies - actually converge and cohabit in the period before the $1620 \mathrm{~s}-30$ s when, as we shall see, the crossover between arte and amateur theatrical styles became more widely consolidated? To answer this, let us now turn to two cases around the end of the sixteenth century where actors were involved with literary academies.

\section{Adriano Valerini and the Accademia Filarmonica of Verona}

My earliest example is of the celebrated actor, Adriano Valerini (c. 1546-c. 1592), a comico famed for his role as lover (innamorato) in the Gelosi company, who made various approaches to the local Accademia de' Filarmonici [Philharmonic Academy] of Verona in the 1580s. Founded in 1543, this academy was known especially for its exceptional musical activities, but it also staged scripted comedies and pastoral plays from 1549 - including notably, an early production of Tasso's Aminta (1581). Valerini's print publications show from the start how he cultivated academies favourable to theatre to elevate his social status by association, and presumably to gain patronage. His first and best known work, probably the first of any arte 
actor in print, was compiled to celebrate his beloved colleague in the Gelosi, Vincenza Armani, on her untimely death in 1569 , a publication which would spawn a fertile tradition of literary compilations for female actors and singers. Valerini's oration alludes to the praise of the Intronati Academy of Siena - in which there flourished 'the cult of the stage' - for Armani's eloquence in improvised performance, which exceeded that of the most expert authors 'in carefully contemplated writing'.45 This is the only direct reference to a cultural authority in the work, and is confirmed in the closing collection of verse by two sonnets by the Intronati (or by a key member, Scipione Bargagli, as Laura Riccò suggests).46 Additionally, there is verse here by the Accademia degli Ortolani, by Leone de' Sommi the Jewish semi-professional dramatist for the Invaghiti academy of Mantua (but identified only as L.S.H.), and by the Filarmonici Academy member Francesco Mondella, who would later author a Senecan tragedy (Irifile, 1582) in the manner of Valerini's Afrodite (1578).

In 1583, when the actor was domiciled in Verona with his family, Valerini is recorded as having sent to the Filarmonici a possibly autograph manuscript copy (now lost) of Count Federico Asinari's still unprinted tragedy Tancredi, with a dedication.47 The summary of the manuscript atti of the academy notes that it was judged according to the usual procedures for works submitted to them by a committee of three members. No subsequent verdict or recognition is recorded, which is intriguing particularly since the play would later be pirated by a fellow actor, Bernardino Lombardi, and printed under the false name of Torquato Tasso as $L a$ Gismonda, tragedia (Paris, 1587). The correct attribution was exposed in the 1588 edition by Gherardo Borghini, who was close to Isabella Andreini.48 It is possible then that Valerini was hoping to gain credit with the Filarmonici by supplying a rare manuscript copy of a text then circulating among actors, perhaps because he was aware of their interest in theatre.

Three years later, Valerini tried a different approach. His lengthy prose encomium of his native city, Le bellezze di Verona (Verona, 1586), contains a section explicitly praising the celebrated local academy.49 It is very likely, as Gian Paolo Marchi has suggested, that the actor hoped thereby to curry favour with the local cultural, civic and religious authorities, so as to receive a permanent licence to perform in the city. Certainly, like his other eight existing printed works, the Bellezze shows off his humanist erudition and his close contacts with important intellectual and aristocratic circles in the city - but, significantly, it makes no mention of his status as an actor. Valerini seems intent on positioning himself as a literato, already with privileged access to cultural networks, in his bid for more public recognition from the most famous lay cultural institution of the city.50 Nonetheless, it is perhaps no coincidence that this encomium appeared shortly after the inaugural performance of the Olympic Theatre in nearby Vicenza, at a time when we know that the Filarmonici were themselves engaged in semi-private theatrical performances, including the staging twice of Antonio Ongaro's pastoral play Alceo.51

Despite these approaches to the Accademia Filarmonica there is no indication of any official acknowledgement of Valerini on their part. This could of course simply be down to the patchy state of the archival documentation for these years. It seems unlikely that this was solely because of the actor's modest family background, since he had a humanist training and highly placed connections. Although the academy was increasingly becoming populated by noblemen, it still admitted professional members who were of lower social extraction, including the highprofile painters, Domenico Brusasorci and later his son Felice (who appear to have been involved with the academy theatricals), as well as musicians of great renown - though these did not always have full membership status.52 It seems probable, therefore, that the academy ignored Valerini because of his status as an arte actor, perhaps exacerbated by his association with Armani and other actresses. They doubtless wished to avoid any potential run-ins over the issue of theatre with the civic and religious authorities of Verona - both of which were strongly opposed to secular dramatic performances. Notably, in 1591 the authorities even turned down a request by the Duke of Mantua to allow his troupe (headed by Valerini) to perform there.53 Even so, there must have been a strong and continued local interest in comici in this period, given the 
unprecedented success with Veronese presses of the pastoral play Mirtilla (published in Verona in 1588, in two editions, and again in 1599) by the actress Isabella Andreini.54

Archival evidence about the Filarmonici provides a somewhat different picture. There are suggestions that they cultivated amateur theatre in a private, even secretive manner; and some prominent members also had connections - probably in less official contexts - with professional comici, including Valerini. Some new evidence of this is suggested by a manuscript verse anthology in the State Archive of Verona, which has hitherto been examined only in relation to music.55 The volume posthumously commemorates Alberto Lavezzola, an honoured 'padre' (protector) of the academy, who was clearly interested in theatre. This manuscript contains sonnets by and for Valerini among verse by Lavezzola himself and various letterati, including several Filarmonici members and other Veneto dramatists. One presumably posthumous sonnet appears to commemorate Valerini's tragedy, Afrodite (Verona, 1578):

Per Adriano Valerini, al suo tempo comico famoso

Come possa un meschin ne i lacci involto

Chieder mercè da duo benigni lumi

Come il foco eshalar, che lo consume

Far men grave il dolor nel petto accolto

Come di donna far cader dal volto

Di freddo cor, di perfidi costume

Per la pietà duo lagrimosi fiumi,

Valerin mostri in stil purgato, e colto.

Per dar conforto a l'amorosa piaga

E quetar nostre passioni acerbe

Huopo non è di Circe, o di arte maga

Or, che poi senza incanti, o succhi di herbe

D’alma sdegnosa, e d'ogni stratio vaga

Le voglie humiliar crude, e superbe.

\section{[For Adriano Valerini, in his day a famous actor}

How a poor wretch caught in love's snares / can beg for mercy from a pair of kind eyes; / how releasing the fire that consumes him / can lessen the heavy grief in his heart; / how he can make the eyes of a cold-hearted, / treacherous-natured lady start to flow / with twin rivers of tears out of pity:/ let Valerini show all this in his pure and learned style. / But to comfort my wounds of love / and to calm my bitter passions / there is no call for Circe or magic arts, / now that without enchantments or herbal draughts, / you can humiliate the cruel and bold will / of a disdainful and blood-thirsty soul.]

This poem clearly celebrates Valerini's rather gruesome tragedy for its learned style ('stil purgato, e colto', l. 8) as well as for its masterly control of the affects, aspects that suggest a learned appreciation probably in circles that overlapped with the Filarmonici. The rime involving Valerini and other theatrical figures in the manuscript are, however, not found in the printed volume put together for Lavezzola posthumously by Francesco Mondella (Rime del S. Alberto Lavezzola, Verona, 1583). 
Valerini also seems to have had contacts with another 'protector' of the academy, Count Mario Bevilacqua, who headed a famous private musical and cultural gathering (ridotto) in his Verona palace. Kathryn Bosi has indicated that this aristocrat knew and supported various actors and dramatists in Verona (and Vicenza), including Isabella Andreini and Valerini, from the late 1580s. There seems to be some reference to this relationship in the considerably annotated copy of Valerini's verse collection, Rime diverse (1577), dedicated to Bevilacqua, which is held in the Accademia Filarmonica library.56 The undated comments, to my knowledge not previously examined, would in another context merit further discussion, especially for their sometimes negative judgements on style. A later manuscript inventory (1628) shows that two further editions of Valerini's works (now lost) - but not his tragedy - were held in the academy. Whatever dealings Valerini had with the Filarmonici, therefore, seem to have been at a purely private and not an officially recognized level. Finally, it seems that Valerini gave up on this avenue for patronage in the face of the Filarmonici's lack of interest, and decided to dedicate his last work to the Olympic Academy of Vicenza.57

\section{Isabella Andreini's Academic Networks}

The Filarmonici appear to have officially maintained this blind spot for more 'public' and controversial forms of theatre also later on. Curiously, when Battista Guarini was accepted as an 'absent' member in 1601, the academy minutes note his 'dottiss[im]e prose, et le leggiadrissime rime' [most learned prose and delightful verse], but do not even mention his dramatic masterpiece, Il Pastor fido, which had by then attracted much debate in other academies in the Veneto region.58 So it is perhaps not surprising that when in the following year (June 1602) the famous actress, Isabella Andreini, sent the Filarmonici an encomiastic sonnet, the academicians agreed to honour her with a reply, but avoided a corporate response, which some feared the actress would print. Instead, an individual member was asked to respond, and five other members voluntarily did likewise.59

Importantly, though, the Filarmonici could not ignore this grande dame of the stage (now aged forty) as they had done Valerini. In contrast to her fellow Gelosi member, Isabella's reputation was founded not only on virtuosity and learning, but also on personal virtue bolstered by her patronage by Cardinal Cinthio Aldobrandini, as well as important friends in exclusive cultural circles including that of Cardinal Federico Borromeo in Milan and the Accademia degli Inquieti in the same city. Importantly, she was an academic equal, as in 1601 she had been made a member of the distinguished Accademia degli Intenti of Pavia. Her membership of the academy was preceded by many years of literary and social connections with academy members and local elites, such as Gherardo Borgogni, and was reinforced by publications and regular performances in the nearby capital Milan from the 1570s.60 Her invitation to join the Intenti was probably precipitated more specifically by the recent publication of her very first organic volume of Rime printed under her own name, dedicated to Aldobrandini in Milan (1601). This successfully advertised her highly placed contacts and her innovative poetic skills, both of which she would have known were of interest to the Intenti. In addition, she may have been extended membership in recognition of her 'diplomatic' role in performing with her troupe in Pavia in March 1601, at the time of a political conclave involving the papal legate Cardinal Pietro Aldobrandini, the Duke of Savoy and the governor of Milan, Conte de Fuentes.61

When Isabella joined the Intenti (founded in 1593 by two members of the Barnabite order), the Academy included numerous prominent ecclesiastics (such as Cardinals Cinthio Aldobrandini and Federico Borromeo) as well as several secular princes. In addition, there were political authorities and other civic officials, university professors and intellectuals from across the arts and sciences. The institution had a strong interest in politics and poetry, as well as music; but it seems unclear whether they were engaged in theatrical activities too.62 Andreini 
and her company were certainly performing in Pavia by 12 March 1601 and were working in Milan the following summer. She had become a member of the Pavia academy by 14 November, where she apparently stayed at least until 24 December. In the following year Andreini returned to Milan in April, and she was in Pavia again in December, when Spelta was completing the Aggionta to his Historia, a work which shows his strong interest in political and carnival spectacle. He records her 'exquisite eloquence' in Pavia in the winter of 1601, and her performance of a pastoral play which inspired him to write verse and an encomium for her, perhaps as a collegial gesture.63 So if Andreini actually attended academic gatherings during her stays in the city, and performed or improvised verse or dramatic works there, or contributed to debates and lectures, one wonders how she did this, unless chaperoned, without contravening decorum, as the sole representative of her sex in the academy. This was of course a problem for the exceptional few female academicians generally.

However, as mentioned, there were precedents of actresses/singers in the Olimpici of Vicenza, and of singers like Vittoria Archilei performing for private male gatherings involving clergymen. Isabella Andreini is also said (perhaps not reliably) to have improvised poetry in the domestic 'academy' of Cardinal Aldobrandini in Rome.64 On an official level, the admission of Andreini as an iconic virtuosa performer and poet would undoubtedly have been calculated to raise the profile of the Intenti to rival their sister-academy, the Affidati, which included two other female poets or singers.65 This pattern of academic rivalry with female figure-heads has been identified by Virginia Cox also in other academies, and compares interestingly with commedia dell'arte groups - often known by their leading actress.

For Andreini herself, this membership of a literary academy apparently brought her the award of a doctoral degree ('laurea dottorale') and further opportunities for patronage as well as for display of her erudition and poetic expertise.66 Notably, her verse is featured straight after the dedicatory letter to Antonio Maria Spelta's La curiosa e dilettevole aggionta, 1602. This also describes the actress's aggregation to the academy and presents a glowing tribute to her as well as showcasing four more of her poems, all of which were included in the second edition of her Rime (Milan, 1605, Part 2). This posthumous volume, which Chiara Cedrati argues Isabella Andreini had probably in large part organized herself for a re-edition in 1602, highlights the actress's membership of the Intenti Academy both visually and poetically, by including in Part 2 various new poetic exchanges with this academy and its members, as well as with the Filarmonici of Verona and the Olimpici of Vicenza.67 This seems to prove the point made by Bruni and Barbieri that academic membership added dignity to actors and their profession. Yet, curiously, in Part 3 Andreini's earlier play, Mirtilla, though presented again as a composition of a 'Comica Gelosa e Accademica Intenta', is addressed to and invokes a specifically female rather than an academic (male) audience.68 Like Valerini, Andreini's academic identity seems therefore to be deliberately and predominantly connected with her status as a poet rather than as a dramatist or arte performer.

\section{Giovan Battista Andreini, comico-accademico}

The two facets seem to have been combined in the case of her son, Giovan Battista Andreini, a distinguished comico and letterato who was associated with the Accademia degli Spensierati of Florence from 1604. This private academy functioned relatively independently from the circuits of grand-ducal power, and was connected to broader literary, religious and political circles across northern Italy in which Isabella operated. As Fabrizio Fiaschini has analysed in detail, the publications of the academy members reflect a growing openness to experiments with mixed genres and the contamination of verse, musical and theatrical forms, as practised also in other contemporary, private Florentine academies.69 Importantly, Andreini's wife, the great actress and singer Virginia Ramponi, known by the stage name 'Florinda', seems to have been a stimulus in this respect. Circumstantial evidence suggests that she may have made her debut in 
the title role of her husband's tragedy Florinda, performed in some way (but not fully staged) for the Spensierati in 1604, or have been involved in other performances. However, there is no direct confirmation of this in the sole surviving printed edition of Florinda from 1606 (the 1604 edition was apparently destroyed by the author because Acts iv and v were poorly printed).70 Nonetheless, this lavish edition, which features an engraving of the author and another depicting the stage setting (entitled 'La scena si finge nelle Foreste di Scozzia' fol. 12/B2v), is introduced by a small collection of verse, 'Sonetti D'Alcuni Illustriss. Signori Accademici Spensierati, Et altri dotti Scrittori, in lode dell'Opera, e dell'Autore', of which the first two of the seven authors are prominently identified as Spensierati members. Furthermore, the first of Virginia Ramponi Andreini's two sonnets included here is composed for the Spensierati Academy 'in ringratiamento d'alcune Rime sopra di lei da gli stessi composte' [to thank them for some verse which members composed about her]. Emily Wilbourne has argued that the actress is referring here to a small printed collection of verse by five Spensierati from 1604, which were composed alongside ones for Florinda, of which others were perhaps lost with the earlier destroyed edition. This tragedy and Andreini's other three printed works connected with the academy mark a crucial first stage of his strategy for self-affirmation and to ennoble his profession.71 In turn, it has been argued by Wilbourne that the academicians were influenced in their compositions by Virginia Andreini's performance.

From the early decades of the seventeenth century some comici were becoming more accepted and their performance styles were even imitated in polite, literary society, reflecting a growing interest in novel, hybrid dramatic forms mixing styles and genres, following a trend for which Guarini was an important pioneer. Numerous 'academies' of a more open and less formal type, devoted to theatrical activities, began to be formed especially in Florence and Rome (until 1627) involving skilled amateur actor-dramatists like Giovanni Briccio, who wrote and performed plays based on or incorporating the improvised dialect comedy of professionals (commedia ridicolosa).72 In Naples, Don Pedro Fernandez de Castro, viceroy between 1610 and 1616, also founded an 'academy' of noble amateur actors at Court. The Immobili [The Immobile Academy] of Florence, headed by Jacopo Cicognini, were heavily involved in improvised performances and even began to run a private theatre with Medici support from c. 1650.73 As Nicolò Barbieri observed in his famous defence of the arte (La supplica, 1634): 'I comici mercenari sovente recitano le stesse [commedie] delle accademie e perciò sono onorati' [professional actors often perform the same [comedies] as academies and for this reason they are honoured]. At the same time, it seems, the professional actor Pier Maria Cecchini planned to set up an 'accademietta' in Rome in which amateurs could be trained privately.74 Nonetheless, the rapport between amateurs and professionals was destined to remain problematic and the two groups followed broadly separate pathways throughout the seventeenth century.75

Characteristically, Giovan Battista Andreini made theatrical capital of this blurred and changing relationship between specialized arte practitioners and their amateur counterparts in one of his most self-consciously meta-theatrical comedies, Le due commedie in commedia [Two Comedies in One] (1623). The title refers to two 'improvised comedies' (with arte characters) that are staged in a private courtyard for the same Venetian audience, first by a group of 'accademici' and then by a professional company. This sets up an implicitly competitive structure of the kind beloved in commedia dell'arte performances. Inevitably, the usual distinctions are made between the groups: i.e. the comici are itinerant and paid, but, predictably, they are also more inventive and skilled than the accademici. As usual, there is also much ambiguity: Lelio (the nome d'arte of Andreini himself) directs and acts with both groups as well as writing sketches, while we learn that the leader of the comici (Fabio) is in fact an educated nobleman who has often performed in academies.76 Two things are striking about this comedy, I would suggest, in the light of our discussion. Firstly, the term 'accademici' is understood very loosely and informally here, compared to such institutions as the Filarmonici and Intenti at least: this is simply a group of pseudo-courtly amateur performers, friends and servants of a wealthy patron, who meet at his house to perform plays for which they are trained. Secondly, 
the female performers play a key role in the group's overall success. The 'accademici' perform with the patron's daughter, Lidia, a talented amateur, while the all-male group of comici are allotted the patron's skilled musician-actress, Florinda (nome d'arte of Virginia Ramponi), whose particularly moving qualities in the final act bring about the full moral and Christian potential of theatre which Andreini promoted.

Andreini's dramaturgy in the early seventeenth century marks a decisive step forward on the part of this actor-literato in re-evaluating the status and function of professional drama, and bridging the 'academic'/'professional' divide. The comedy highlights the increasingly unstable notion of 'academy' over the period, and suggests the critical role of female performers in breaking down divisions between the theatrical practices of 'literary' academies and comici dell'arte - as seen in the cases of Isabella Andreini and Virginia Ramponi - and in encouraging the development of new genres and styles of performance. This the Intronati had already foreshadowed with their strong interest in female characters and, more covertly, in female performers like Vincenza Armani. But as Valerini's rapport with the Filarmonici shows, the task of historically reconstructing such relations seems to be obscured by the mythomania of actors and by self-censorship on an official level by academies, as well as, until recently, by a tendency for disciplinary separatism in modern theatre scholarship. So, to give a provisional answer to my initial question about how far accademici and comici interacted in this period, one might conclude that they did at first occasionally, though rarely openly or corporately. Increasingly, though, the increased blurring between the practices of these groups suggests that the rhetoric of mutual antagonism coexisted with unacknowledged coalescence. 


\section{Appendix}

Extracts from Giovan Battista Andreini,Le due comedie in comedia. Suggetto stravagantissimo

(Venice: Gherardo e Giuseppe Imberti, 1623)

\section{Act II, Scene 3}

Lelio, the servant of Rovenio a nobleman living in Venice, has been asked to stage at short notice a comedy to delight the latter's beloved (Solinga) and various invited locals. In this scene the group of nine male academicians ('accademici') have appeared, whom Lelio has already begun to rehearse and train in improvisation ('parlar all'improviso') together with Rovenio's daughter, Lidia. They will perform a comedy that they have started rehearsing, involving commedia dell'arte masks and entitled Commedia d'incerto fine [Comedy with an Unknown Ending].

Rovenio, Zelandro, Arminia, Filino, Gilenio, Tribino, Alfesimoro, Ricciardo, Rubenio, Terbuono, Lucrano, [Lelio]

Rovenio O signori Accademici, o figliuoli miei amati, quant'obligo a tutti voi tengo! Ma vedete, alla libera, perché sapete ch'io non son corteggiano. Madonna Arminia, Lelio.

Arminia Son qui, signor, per ricever i suoi carissimi comandamenti.

Rovenio Zelandro.

Zelandro Rovenio mio, che volete? Mi pare la vostra casa un museo di virtù.

Rovenio Tale esser doveva per ricever voi, ch'avete del Giove. Messer Filino, la vostra parte?

Filino Eccola in scritto nel foglio, ma stampata poi nella mente.

Zelandro E voi Gilenio, voi Tibrino, voi Alfesimoro, voi Ricciardo, Rubenio, Terbuono, Lucrano, come vanno le cose?

Filino Benissimo, signor, ed ecco come ogni Accademico ha la sua parte in mano e tra sé la va ruminando.

Zelandro A farsi onore, vedete, perché avete Rovenio e che oltre il lodarvi v'ama dicuore. La signora Lidia, figlia del mio caro amico, pur sa benissimo la sua parte, e così ben discorre che sembra comica avvezzata a far pompa di sé ne' maggiori teatri, non solo sparsi per la città, eretti fra le Accademie, ma innalzati da' più famosi principi e più felici regi.

Calandra Son qui, son qui anch'io, fratelli, con la mia parte in mano.

Rovenio Olà, oh ecco il resto del carlino! Zelandro, s'apparecchia, or ora, che appunto abbiam desinato, un bellissimo trattenimento. 


\section{Appendix}

Extracts from Giovan Battista Andreini, Two Comedies in One (1623) (translated by Lisa Sampson)

\section{Act II, Scene 3}

Rovenio, Zelandro, Arminia, Filino, Gilenio, Tribino, Alfesimoro, Ricciardo, Rubenio, Terbuono, Lucrano, [Lelio]

Rovenio 0 noble and dear Academicians of mine, I'm much obliged to you all!Although of course I'm under no obligation myself, because, as you know, I am no courtier. Madonna Arminia, Lelio!

Arminia Here I am, my Lord, eagerly awaiting your every command.

Rovenio Zelandro.

Zelandro My dear Rovenio, what do you want? Your house is like a museum of virtues.

Rovenio Just as it should be to receive you, who resemble Jove himself. Master Filino, where is your part?

Filino Here it is, written down on this sheet, but also imprinted on my mind.

Zelandro And you Gilenio, you Tibrino, you Alfesimoro, you Ricciardo, and Rubenio, Terbuono, Lucrano, how are things coming along?

Filino Very well, my lord, look how all the Academicians are holding their script and thinking it over.

Zelandro So as to gain honour, you see, for you have Rovenio's support; indeed, he praises you and also loves you dearly. Lady Lidia, my dear friend's daughter, knows her part perfectly too and speaks so well that she seems like a professional actress who is accustomed to displaying her virtues in the greatest theatres - not only those in this city, or in Academies but also those of princes of great repute and the highest royalty.

Calandra [Arriving] I'm here now, I'm here too, brothers, and I have my script.

Rovenio Oh look who's here to complete the cast! Zelandro, as soon as we have dined, we can look forward to a treat of a performance. 


\section{Act IV, Scene 2}

After their performance, two of the accademici, Calandro and Filino encounter a troupe of professional comici. Led by the Roman nobleman Fabio, these actors have recently arrived in Venice looking for honour and employment from among the many interested patricians. The scene exposes the pompous and naïve amateur courtier-actors (accademici) to the ridicule of the sophisticated, self-reliant comici, and parodies some of the markers of academy status.

Calandra Vi so dir, Filino, ch'avete filato fil sottile mentre ch'eravate in teatro; con quella parte di Narciso vi farete un grand'Accademico comico.

Filino E voi, Calandra, qual passero solitario, qual caponero, qual rusignolo nella dolcezza della favella vi pareggiò mai? Ma chi son costoro con tant'oro indosso, con tante piume in capo? Sono tutti signori? E dove sono i servi? [...]

Fabio Costoro fanno un gran rimirare, lasciate fare a me. Galantuomini, siete voi stampatori?

Calandra Messer, signorsì, perché? Volete far istampar alcun bando?

Fabio Non bando, ma bandiere.

Calandra Che siete alfieri?

Fabio Alfieri di virtù che in candida bandiera, entrovi affisse note vere, facciamo al comparir di quelle radunar per piazza e per cantoni genti diverse, intente al mirarne ed ammirarne.

Calandra Fratello io non l'intendo. [...]

Fabio Oh povera gente, s'andarebbe dietro un pezzo se con una dolcezza d'un mendicato ambiguo volessi attorniarvi. Il candido stendardo, entrovi affisse note nere, sono que' cartelli di commedie che si veggono per le città, i quali, mentre son letti e per piazza e per cantoni, riducono alle stanze gran numero di popolo. Siamo alfieri di virtù, poiché al vagar di queste insigne per la città invitiamo gente molta a vederne. Ministriamo morti, maneggiamo teste, poiché le tragedie così fatte cose ricercano: siamo comici alfine.

Filino Comici?

Calandra 0 signori comici, che siate benedetti sopra i legni, parlo sui vostri teatri: e noi siamo Accademici.

Orazio Accademici?

Filino Accademicissimi, poiché noi duo siamo i più virtuosi e graziosi.

Calandra Anzi, che or ora abbiamo fatta una commedia intitolata Commedia d'incerto fine, e siamo stati tanto eccellenti ed Accademici senza pari, che una nemicizia di vent'anni abbiamo convertita in pace e parentela; e la nostra Accademia s'addimanda l'Incerta Speranza, per le incertezze che'l nostro capo sperando disperava; ma pure alfine sortì l'effetto conforme alle cose sperate.

Filino Signori comici, se conoscerete la vostra fortuna, noi altri signori Accademici vi favoriremo, e vi faremo guadagnar ben bene; ma se non siete virtuosi, non ci venite a recitar davanti, perché noi altri signori Accademici non vogliam cose se non degne d'Accademia o d'Accademici accademicissimi.

Fabio Sono Accademico anch'io, e mi domando l'Afflitto.

Calandra Ed io il Morto di fame.

Filino Ed io di sete; e la mia impresa è 'l fiasco vuoto col motto: 'Mi muoio di sete, aspettate, aspettate'. Oh di casa! Oh di casa! Signor Rovenio, signor Zelandro, fuori! Fuori Accademici, comici, sine numero! [Bussano]

[Italian text cited from Siro Ferrone, ed., Commedie dell'Arte (Milan: Mursia, 1985), vol. 2, pp. 41-42, 6668.] 


\section{Act IV, Scene 2}

Calandra I can tell you, Filino, you wove a subtle tale while you were in the theatre; you will become a great actor-academician playing the part of Narciso.

Filino As for you, Calandra, what lonely sparrow, tit, or nightingale could ever compare in sweetness to your voice? But who are those men over there all dripping with gold and with those great plumes in their hats? Can they all be masters? Where are their servants? [...]

Fabio Those men over there are observing us closely. Let me deal with them. Gentlemen, are you printers?

Calandra Yes, my Lord, why do you ask? Do you want to have a notice printed?

Fabio Not a notice, but a banner.

Calandra Are you standard-bearers?

Fabio We are standard-bearers of virtue. On seeing our white banner with true signs, all kinds of people gather in the piazzas and on street corners, eager to see and admire us.

Calandra My friend, I don't understand. [...]

Fabio Ah you poor people, we wouldn't get very far if I kept on confounding you with a sweet and deliberate pun. The white standard with black signs refers to the notices of comedies that you see displayed around the cities. When these are read in the piazzas and on street corners they draw large crowds to the halls. We call ourselves standard-bearers of virtue as we invite many people to come to see us by taking these banners around the city. We administer deaths and handle decapitated heads, which are needed for tragedies. We are, you see, a troupe of actors.

Filino Actors?

Calandra 0 gentle Actors, blessed be you on stage - I mean in your theatres. We are Academicians. Orazio Academicians?

Filino Most academic academicians, and we two are the most virtuoso and gracious.

Calandra In fact, we've just performed a comedy entitled Comedy with an unknown ending and we were so skilled - better than all other Academicians - that we converted a twenty-year enmity into peace and a family bond. Our Academy is called the 'Uncertain Hope' because of the uncertainty with which our leader despaired in hope; but in the end what he hoped for came to pass.

Filino Actors, sirs, if you recognize your good fortune, we Academicians will look kindly on you, and have you earn substantially. But if you are not virtuosi don't come before us to perform, because we Academicians want only what is worthy of an Academy and of the most Academic Academicians.

Fabio I'm also an Academician and my nickname is 'The Afflicted'.

Calandra And I'm the 'The Starving Hungry'.

Filino And I'm 'The Parched with Thirst': and my emblem is an empty flask with the motto 'I die of thirst, wait, wait'. Hey, you inside, open up! Open up! Signor Rovenio, Signor Zelandro, come out! Come out all of you Academicians, there's a whole group of actors here! [They knock] 


\section{Bibliography}

\section{Archival sources}

Archivio di Stato, Verona

Fondo Dionisio-Piomarta, ms 634, Summario degli atti dell'Accademia Filarmonica

Fondo Dionisio-Piomarta, ms 637, Rime dedicated to Alberto Lavezzola

Archivio dell'Accademia Filarmonica, Verona

Atti dell'Accademia Filarmonica, b. 41

\section{Printed works}

Albonico, Simone, ed., 'Sul Tesin piantāro laureti': poesia e vita letteraria nella Lombardia spagnola (15351706) (Pavia: Cardano, 2002)

Alonge, Roberto, and Guido Davico Bonino, eds, Storia del teatro moderno e contemporaneo (Turin: Einaudi, 2000)

Andreini, Isabella, Rime (Milan: Appresso Girolamo Bordone, \& Pietromartire Locarni, 1605)

-_ La Mirtilla. Fauola pastorale ... Di nuouo dall'istessa riueduta, et in molti luoghi abbellita (Verona: per Francesco dalle Donne, \& Scipione Vargnano suo genero, 1599)

- - Mirtilla (Verona: Girolamo Discepolo, 1588; Sebastiano dalle Donne and Camillo Franceschini, 1588)

Andrews, Richard, Scripts and Scenarios: The Performance of Comedy in Renaissance Italy (Cambridge: Cambridge University Press, 1993)

Arcaini, Roberta Giovanna, 'I comici dell'arte a Milano: accoglienza, sospetti, riconoscimenti', in La scena della Gloria: drammaturgia e spettacolo a Milano in età spagnola, ed. by A. Cascetta and R. Carpani (Milan: Vita e pensiero, 1995), pp. 268-76

Barbieri, Nicolò, Discorso famigliare ... (Venice, 1628), in La commedia dell'arte, Pandolfi, iii, 369-98

Bosi, Kathryn, 'Accolades for an Actress: On Some Literary and Musical Tributes for Isabella Andreini', Recercare, 15 (2003), 73-117

Boutier, Jean, and Maria Pia Paoli, 'Letterati cittadini e principi filosofi: i milieux intellettuali fiorentini tra cinque e settecento', in Naples, Rome, Florence: une histoire comparée des milieux intellectuels italiens (XVIIe-XVIIIe siècles), ed. by Jean Boutier, Brigitte Marin and Antonella Romano (Rome: École Française de Rome, 2005), pp. 331-403

Bruni, Domenico, Fatiche comiche di Domenico Bruni detto Fulvio, Comico di Madama Serenissima Principessa di Piemonte (Paris, 1623), in Marotti and Romei, La commedia dell'arte e la società barocca, ii, $347-48$

Calendoli, Giovanni, 'Le Compagnie della Calza, Ruzante e la compagnia Padovana del 1545', in Il convegno internazionale di studi sul Ruzante, ed. by Giovanni Calendoli and Giuseppe Vellucci (Venice: Corbo e Fiore, 1989), pp. 325-31

Campiglia, Maddalena, Flori: A Pastoral Play [1588], ed. by Virginia Cox and Lisa Sampson, trans. by Virginia Cox (Chicago, IL: Chicago University Press, 2004)

Cedrati, Chiara, 'Isabella Andreini: la vicenda editoriale delle "Rime" ', ACME - Annali della Facoltà di Lettere e Filosofia dell'Università degli Studi di Milano, 60.2 (May-August 2007), 115-42 $<$ http://www.ledonline.it/acme/allegati/Acme-07-II-05-Cedrati.pdf>

Cocco, Ester, 'Una compagnia comica nella prima metà del secolo XVI', Giornale storico della letteratura italiana, 65 (1915), 50-70

Comi, Siro, Ricerche storiche sull'accademia degli Affidati e su altri analoghi stabilimenti in Pavia (Pavia: Comino, 1792)

Cox, Virginia, The Prodigious Muse: Women's Writing in Counter-Reformation Italy (Baltimore, MD: Johns Hopkins University Press, 2011)

- - Women's Writing in Italy, 1400-1650 (Baltimore, MD: Johns Hopkins University Press, 2008)

Crimi, Giuseppe, 'Appunti per il testo e il commento delle Lettere di Cesare Rao', in Dissonanze concordi: temi, questioni e personaggi intorno ad Anton Francesco Doni, ed. Giovanna Rizzarelli (Bologna: Il Mulino, 2013), pp. 353-74

Della Valle, Camillo, Fillide, egloga pastorale (Ferrara: Vittorio Baldini, 1584)

- - [attrib.] La Fillide, fauola pastorale, dell'Acceso Academico Rinouato (Ferrara: Vittorio Baldini, 1579)

Di Pasquale, Marco, 'Intorno al patronato della musica della Accademia Filarmonica di Verona nel Cinquecento: riflessioni e congetture', Recercare, 23.1-2 (2011), 35-63

Fenlon, Iain, Music and Patronage in Sixteenth-Century Mantua, 2 vols (Cambridge: Cambridge University Press, 1980) 
Ferrone, Siro, 'La Commedia dell'Arte senza commedia', Biblioteca teatrale, 3 (2011), 163-74

- - Attori mercanti corsari: la Commedia dell'Arte in Europa tra Cinque e Seicento (Turin: Einaudi, 1993)

- - ed., Comici dell'Arte: corrispondenze, 2 vols (Florence: Le Lettere, 1993)

- - ed., Commedie dell'Arte, 2 vols (Milan: Mursia, 1985)

Fiaschini, Fabrizio, L'Incessabil agitazione': Giovan Battista Andreini tra professione teatrale, cultura letteraria e religione (Pisa: Giardini, 2007)

Fumaroli, Marc, 'Academia, Arcadia, Parnassus: trois lieux allégoriques de l'éloge du loisir lettré', in Italian Academies of the Sixteenth Century, ed. by D. S. Chambers and F. Quiviger (London: Warburg Institute, 1995), pp. 15-35

Gallo, Alberto, La prima rappresentazione al Teatro Olimpico, con i progetti e le relazioni dei contemporanei, preface by Lionello Puppi (Milan: Il Polifilo, 1973)

Guarini, G. B., Compendio della poesia tragicomica tratto dai duo Verati [1602], in Il Pastor fido e Compendio della Poesia Tragicomica, ed. by Gioachino Brognoligo (Bari: Laterza, 1914), pp. 219-88

-_ Delle Opere del Cavalier Battista Guarini, 4 vols (Verona: Tumermani, 1737-38)

Henke, Robert, Performance and Literature in the Commedia dell'Arte (Cambridge: Cambridge University Press, 2002)

Ingegneri, Angelo, Della poesia rappresentativa e del modo di rappresentare le favole sceniche [1598], ed. by Maria Luisa Doglio (Modena: Panini, 1989)

Johnson, Eugene J., 'The Short, Lascivious Lives of Two Venetian Theaters, 1580-85', Renaissance Quarterly, 55.3 (2002), 936-68

MacNeil, Anne, Music and Women of the 'Commedia dell'Arte' in the Late Sixteenth Century (Oxford: Oxford University Press, 2003)

Maino, Marzia, 'Dispositivi illuminotecnici e spettacolo a Vicenza: L'Accademia Olimpica, l'inaugurazione del Teatro e gli influssi sul contesto spettacolare' (unpublished PhD dissertation, Padua University, 2009)

Mamone, Sara, Dèi, Semidei, Uomini: lo spettacolo a Firenze tra neoplatonismo e realtà borghese (XV-XVII secolo) (Rome: Bulzoni, 2003)

Marchi, G. P., 'L'esperienza teatrale di Adriano Valerini', in La commedia dell'arte tra Cinque e Seicento in Francia e in Europa. Atti del Convegno Internazionale di Studio, Verona-Vicenza, 19-21 Oct. 1995, ed. by Elio Mosele (Fasano: Schena, 1997), pp. 173-80

Marcigliano, Alessandro, 'Giovan Battista Verato: un attore nella Ferrara del Cinquecento', in Scenery, Set and Staging in the Italian Renaissance: Studies in the Practice of Theatre, ed. by Christopher Cairns (Lewiston, NY: Edwin Mellen, 1996)

Mariti, Luciano, Commedia ridicolosa: comici di professione, dilettanti, editoria teatrale nel Seicento, storia e testi (Rome: Bulzoni, 1979)

Marotti, Ferruccio, and Giovanna Romei, La commedia dell'arte e la società barocca. 2. La professione del teatro (Rome: Bulzoni, 1991)

Masi, Giorgio, 'Coreografie doniane: L'Accademia Pellegrina', in Cinquecento capriccioso e irregolare: eresie letterarie nell'Italia del classicismo, ed. by Paolo Procaccioli and Angelo Romano (Rome: Vecchiarelli, 1999), pp. 45-85

Materassi, Marco, Il Primo Lauro. Madrigali in onore di Laura Peperara. Ms 220 dell'Accademia Filarmonica di Verona [1580] (Treviso: Diastema Fiori Musicali, 1999) <http://web.tiscali.it/ensemble900/Diastema/Libri/Schede/Materassi.pdf>

Maylender, Michele, Storie delle Accademie d'Italia, 5 vols (Bologna: Cappelli, 1926-30)

Mazzoni, Stefano, 'Lo spettacolo delle accademie', in Alonge and Davico Bonino, eds, Storia del teatro moderno e contemporaneo, pp. 869-903.

- - L'Olimpico di Vicenza: un teatro e la sua 'perpetua memoria' (Florence: Le Lettere, 1998)

- - 'Genealogia e vicende della famiglia Andreini', in Origini della Commedia Improvvisa o dell'Arte, ed. by

M. Chiabò and F. Doglio (Rome: Torre d'Orfeo, 1996), pp. 107-61

Megale, Teresa 'Lombardi, Bernardino', DBI 65 (2005), $<$ http://www.treccani.it/enciclopedia/bernardino-lombardi_(Dizionario-Biografico)/>

Palisca, Claude V., 'The Alterati of Florence, Pioneers in the Theory of Dramatic Music', in New Looks at Italian Opera: Essays in Honor of Donald J. Grout, ed. with intro. by William W. Austin (Ithaca, NY: Cornell University Press, 1968), pp. 9-38

- - 'The First Performance of Euridice', in Queens College Department of Music: Twenty-fifth Anniversary Festschrift, ed. by Albert Mell (New York: Queens College Press, 1964), pp. 1-23

Pandolfi, Vito, ed., La commedia dell'arte: storia e testi, 6 vols (Florence: Sansoni, 1957-1961)

Pieri, Marzia, ' "Il Pastor fido" e i comici dell'arte', Biblioteca teatrale, 17 (1990), 1-15 
Pignatti, Franco, 'Grazzini, Antonfrancesco (detto il Lasca)', Dizionario Biografico degli Italiani, 59 (2002); online at <http://www.treccani.it/enciclopedia/antonfrancesco-grazzini_\%28Dizionario Biografico\%29/>

Pirrotta, Nino, and Elena Povoledo, Music and Theatre from Poliziano to Monteverdi, trans. by Karen Eales (Cambridge: Cambridge University Press, 1982)

Povoledo, Elena, 'Una rappresentazione accademica a Venezia nel 1634', in Studi sul teatro Veneto fra rinascimento ed età barocca, ed. by Maria Teresa Muraro (Florence: Olschki, 1971), pp. 119-69

Quondam, Amedeo, 'L'Accademia', in Letteratura italiana, I, Il letterato e le istituzioni (Turin: Einaudi, 1982), pp. 823-98

Rao, Cesare, L'Argute et facete lettere [...] nelle quali si contengono molti leggiadri Motti, \& solazzevoli Discorsi (Vicenza: Appresso Perin Libraro, \& Giorgio Greco compagni, 1585)

Regali, Maria Cristina, 'Le ricerche storiche sull'Accademia degli Affidati di Siro Comi: edizione delle postille dell'autore' (Como: Litografia New Press, 1999)

Riccò, Laura, La 'miniera' accademica: pedagogia, editoria, palcoscenico nella Siena del Cinquecento (Rome: Bulzoni, 2002)

Rigoli, Paolo, 'L'architettura effimera: feste, teatri, apparati decorative', in L'architettura a Verona nell'età della Serenissima (sec. XV-sec. XVIII), ed. by Pierpaolo Brugnoli and Arturo Sandrini, 2 vols (Verona: Banca popolare di Verona, 1988), i, 1-86, 391-414

Sampson, Lisa, Pastoral Drama in Early Modern Italy: The Making of a New Genre (Oxford: Legenda, 2006)

Saslow, James M., The Medici Wedding of 1589: Florentine Festival as Theatrum Mundi (New Haven, CT: Yale University Press, 1996)

Seragnoli, Daniele, Il teatro a Siena nel Cinquecento: 'progetto' e 'modello' drammaturgico nell'Accademia degli intronati (Roma: Bulzoni, 1980)

Spelta, Antonio Maria, Historia ... De' fatti notabili occorsi nell'universo, \& in particolare del Regno de' Gothi, de' Longobardi, de i Duchi di Milano, [...] Con una nuova aggiunta (Pavia: Pietro Bartoli, 1602)

Tamburini, Elena, ' "Comedia dell'arte": An Enquiry and Some Incursions into the Meaning of This Term', trans. by Mark Weir, Acting Archives Essays, 15 (April 2012), 1-35 [from ' "Commedia dell'arte": immagini e percorsi intorno a un'ipotesi', Drammaturgia, 5 July 2010, <www.drammaturgia.it>)

_- 'Comici, cantanti e letterati nell'Accademia Romana degli Umoristi', Studi Secenteschi, 50 (2009), 89112

-_ 'I comici Gelosi e l'Accademia della Val di Blenio', Teatro e storia, 3 (2011), 175-96

Taviani, Ferdinando, ' "Bella d'Asia”: Torquato Tasso, gli attori e l'immortalità', Paragone letteratura, 35 (1984), 3-76

Tessari, Roberto, 'Il mercato delle Maschere', in Alonge and Davico Bonino, eds, Storia del teatro moderno e contemporaneo, pp. 119-91

- - La Commedia dell'arte nel Seicento: 'industria' e 'arte giocosa' della civiltà barocca (Florence: Olschki, 1969)

Turrini, G., L'Accademia Filarmonica di Verona dalla fondazione (Maggio 1543) al 1600 e il suo patrimonio musicale antico (Verona: Tipografica Veronese, 1941)

Valerini, Adriano, Le bellezze di Verona [1586], ed. by G. P. Marchi (Verona: Stamperia Valdonega, 1974)

- - Rime diverse et origine della famiglia della famiglia Bevilacqua (Verona: per Sebastiano dalle Donne e fratelli, [1577])

- - Oratione ... In morte della Divina Signora Vincenza Armani, Comica Eccellentissima. Et alcune rime dell'Istesso e d'altri Auttori, in lode della medesima. Con alquante leggiadre e belle Compositioni di detta Signora Vincenza (Verona: Per Bastian dalle Donne, \& Giovanni Fratelli, n.d. [1570?])

Vazzoler, Franco, 'Chiabrera fra dilettanti e professionisti dello spettacolo', in La scelta della misura. Gabriello Chiabrera: l'altro fuoco del barocco italiano, ed. by Fulvio Bianchi and Paolo Russo (Genoa: Costa \& Nolan, 1993), pp. 429-66

Wilbourne, Emily, 'La Florinda: The Performance of Virginia Ramponi Andreini' (unpublished PhD dissertation, New York University, 2009)

'“Isabella ringiovinita": Virginia Ramponi Andreini before Arianna', Recercare, 19.1-2 (2007), 54-67

Zanré, Domenico, Cultural Non-conformity in Early Modern Florence (Aldershot: Ashgate, 2004)

Zapperi, Ada, 'Barlachia (Barlacchia, Barlacchi), Domenico', DBI, 6 (1964)

\section{Web-based resources:}

British Library Database of Italian Academies (1525-1700):

$<$ http://www.bl.uk/catalogues/ItalianAcademies/>

Dizionario Biografico degli Italiani: <http://www.treccani.it/biografie/> 
Cox, Virginia, 'Members, Muses, Mascots: Women and Italian Academies', conference paper delivered at 'The Italian Academies, 1525-1700: The First Intellectual Networks of Early Modern Europe', 17 September 2012, British Library, London. Available as a podcast on: <http://backdoorbroadcasting.net/2012/09/virginia-cox-members-muses-mascots-women-anditalian-academies/>

Sampson, Lisa, 'Gir' in porto a le degn'opre Intenta": Isabella Andreini and the Intenti Academy of Pavia' [2014], podcast on <http://www.casaitaliananyu.org/content/isabella-andreini-and-intenti-academypavia-2014> 


\section{Notes to Chapter 9}

This research has been supported by the Arts and Humanities Research Council UK as part of the Italian Academies, 1525-1700 project [ref. AH/H023631/1], and by a Gladys Krieble Delmas Foundation grant. I am grateful for the comments of Jane Everson and the editors in preparing the essay.

1. Domenico Bruni, Fatiche comiche di Domenico Bruni detto Fulvio, Comico di Madama Serenissima Principessa di Piemonte (Paris, 1623), in Ferruccio Marotti and Giovanna Romei, La commedia dell'arte e la società barocca. 2. La professione del teatro (Rome: Bulzoni, 1991; repr. 1994), pp. 347-48. This quotation appears in 'Prologo da ragazzo' [Prologue played by a boy], which Bruni claims he was instructed to recite as a boy by Francesco Andreini, husband of Isabella and father of Giovan Battista. All translations are mine, except where indicated.

2. 'molti comici per mezzo dell'Arte loro si sono resi capaci di molti honori havuti da Imperatori, da Regi, da Principi, e da Illustrissime Academie' [several actors have through the development of their Art gained many honours from emperors, kings, princes and most illustrious academies] (Nicolò Barbieri, Discorso famigliare... (Venice, 1628), in La commedia dell'arte: storia e testi, ed. by Vito Pandolfi, 6 vols (Florence: Sansoni, 1957-1961), iii, 369-98). However, like Bruni, Barbieri only provides specific details for academy membership for Isabella and Giovan Battista Andreini.

3. Richard Andrews, Scripts and Scenarios: The Performance of Comedy in Renaissance Italy (Cambridge: Cambridge University Press, 1993), p. 168.

4. For notarized contracts and other documents regarding this group of eight, mostly artisanal, actors, see Ester Cocco, 'Una compagnia comica nella prima metà del secolo XVI', Giornale storico della letteratura italiana, 65 (1915), 55-70; Robert Henke, Performance and Literature in the Commedia dell'Arte (Cambridge: Cambridge University Press, 2002), pp. 69-74.

5. Roberto Tessari, 'Il mercato delle Maschere', in Storia del teatro moderno e contemporaneo, ed. by Roberto Alonge and Guido Davico Bonino (Turin: Einaudi, 2000), pp. 119-91 (citation p. 119). On Grazzini, the author of eight surviving prose comedies, see also Franco Pignatti, 'Grazzini, Antonfrancesco (detto il Lasca)', Dizionario Biografico degli Italiani, 59 (2003); online at <http://www.treccani.it/enciclopedia/antonfrancescograzzini_\%28Dizionario-Biografico\%29/> [accessed 9 September 2013]. On his much studied problematic relations with the Accademia Fiorentina and involvement in alternative cultural spaces, see for example Domenico Zanré, Cultural Non-Conformity in Early-Modern Florence (Aldershot: Ashgate, 2004), pp. 59-85, 14445.

6. Henke, Performance and Literature, p. 78; see also pp. 74-79.

7. For an essential overview, but less focused on the actor, see Stefano Mazzoni, 'Lo spettacolo delle accademie', in Storia del teatro moderno e contemporaneo, ed. by Roberto Alonge and Guido Davico Bonino (Turin: Einaudi, 2000), pp. 869-903. On academy theatre in the Veneto see Elena Povoledo, 'Una rappresentazione accademica a Venezia nel 1634', in Studi sul teatro Veneto fra rinascimento ed età barocca, ed. by Maria Teresa Muraro (Florence: Olschki, 1971), pp. 119-69. See also the studies by Tamburini, Mazzoni, Mamone and Fiaschini cited below, and for Adriano Valerini and Isabella Andreini consult the bibliography.

8. For relations between English actors and the commedia, see Chapter 10, section 3.

9. G. B. Guarini Compendio della poesia tragicomica tratto dai duo Verati [1602], in Il Pastor fido e Compendio della Poesia Tragicomica, ed. by Gioachino Brognoligo (Bari: Laterza, 1914), pp. 219-88 (p. 245). The two earlier treatises on which the Compendio draws (Verato, 1588; Verato secondo, 1593) are named after the distinguished (semi-professional) actor Giovan Battista Verato, who is also defended in the second treatise. For academic hostility to mercenary actors, see Tessari, 'Il mercato delle maschere', pp. 122-23. Compare Angelo Ingegneri, Della poesia rappresentativa e del modo di rappresentare le favole sceniche [1598], ed. by Maria Luisa Doglio (Modena: Panini, 1989), p. 6.

10. Tessari, 'Il mercato delle maschere', p. 123; and his 'Comici e letterati', in La Commedia dell'arte nel Seicento: 'industria' e 'arte giocosa' della civiltà barocca (Florence: Olschki, 1969), pp. 56-68.

11. On the Olimpici, see Marzia Maino, 'Dispositivi illuminotecnici e spettacolo a Vicenza: l'Accademia Olimpica, l'inaugurazione del Teatro e gli influssi sul contesto spettacolare' (unpublished PhD dissertation, Padua University, 2009); Stefano Mazzoni, L'Olimpico di Vicenza: un teatro e la sua 'perpetua memoria' (Florence: Le Lettere, 1998). On the Alterati, see Claude V. Palisca, 'The Alterati of Florence, Pioneers in the Theory of Dramatic Music', in New Looks at Italian Opera: Essays in Honor of Donald J. Grout, ed. with intro. by William W. Austin (Ithaca, NY: Cornell University Press, 1968), pp. 9-38; and his 'The First Performance of Euridice', in Queens College Department of Music: Twenty-fifth Anniversary Festschrift, ed. by Albert Mell (New York: Queens College Press, 1964), pp. 1-23. For the much studied Intronati, see for example Daniele Seragnoli, Il teatro a Siena nel Cinquecento: 'progetto' e 'modello' drammaturgico nell'Accademia degli intronati (Roma: Bulzoni, 1980); and Laura Riccò, La 'miniera' accademica: pedagogia, editoria, palcoscenico nella Siena del Cinquecento (Rome: Bulzoni, 2002).

12. On comici dell'arte as a 'microsocietà', see Tessari, 'Il mercato delle maschere', p. 132; for an interesting exploration of the symbolic and ritual separation inherent in the idea of the academy, see Marc Fumaroli, 'Academia, Arcadia, Parnassus: trois lieux allégoriques de l'éloge du loisir lettré', in Italian Academies of the Sixteenth Century, ed. by D. S. Chambers and F. Quiviger (London: Warburg Institute, 1995), pp. 15-35.

13. James M. Saslow, The Medici wedding of 1589: Florentine Festival as Theatrum Mundi (New Haven, CT: Yale University Press, 1996), esp. pp. 150-62, 169-70; Andrews, Scripts and Scenarios,pp. 227-37. 
14. For important exceptions, see Fabrizio Fiaschini, L'Incessabil agitazione": Giovan Battista Andreini tra professione teatrale, cultura letteraria e religione (Pisa: Giardini, 2007), and the studies of Elena Tamburini.

15. For Guarini, see Marzia Pieri, ' "Il Pastor fido" e i comici dell'arte', Biblioteca teatrale, 17 (1990), 1-15; see also Franco Vazzoler, 'Chiabrera fra dilettanti e professionisti dello spettacolo', in La scelta della misura. Gabriello Chiabrera: l'altro fuoco del barocco italiano, ed. by Fulvio Bianchi and Paolo Russo (Genoa: Costa \& Nolan, 1993), pp. 429-66; Elena Tamburini, “ "Comedia dell'arte”: An Enquiry and Some Incursions into the Meaning of this Term', trans. by Mark Weir, Acting Archives Essays, 15 (April 2012), 1-35 (from ' "Commedia dell'arte”: immagini e percorsi intorno a un'ipotesi', Drammaturgia, 5 July 2010, <www.drammaturgia.it>); and Sara Mamone, Dèi, Semidei, Uomini: lo spettacolo a Firenze tra neoplatonismo e realtà Borghese ( $X V-X V I I$ secolo) (Rome: Bulzoni, 2003).

16. Amedeo Quondam, 'L'Accademia', in Letteratura italiana, I, Il letterato e le istituzioni (Turin: Einaudi, 1982), pp. 823-98 (pp. 870-71). These statistics are acknowledged to be hard to quantify precisely. However, Quondam's analysis is based on the 2,050 institutions that he classifies as academies from the over 2,270 listed in Michele Maylender, Storie delle Accademie d'Italia, 5 vols (Bologna: Cappelli, 1926-30). Maylender's encyclopedia still remains a valuable guide, but recent scholarship has highlighted some inconsistencies, errors and limitations. For ongoing research by the AHRC funded Italian Academies project, see the publicly accessible British Library Database of Italian Academies (1525-1700): <http://www.bl.uk/catalogues/ItalianAcademies/>.

17. Jean Boutier and Maria Pia Paoli, 'Letterati cittadini e principi filosofi: i milieux intellettuali fiorentini tra cinque e settecento', in Naples, Rome, Florence: une histoire comparée des milieux intellectuels italiens (XVIIe-XVIIIe siècles), ed. by Jean Boutier, Brigitte Marin and Antonella Romano (Rome: École Française de Rome, 2005), pp. 331-403 (pp. 371-73); and for an updated alphabetical index of Florentine academies, pp. 684-88.

18. See Mamone, Dèi, Semidei, Uomini, pp. 13-25. On Barlacchia, whose name (meaning 'stupid') recalls facetious academic nicknames, see Ada Zapperi, 'Barlachia (Barlacchia, Barlacchi), Domenico', DBI, 6 (1964), on <http://www.treccani.it/enciclopedia/domenico-barlachia_\%28Dizionario-Biografico\%29/> [accessed 20 August 2013]. See also Alison Brown, 'Defining the place of academies in Florentine culture and politics', forthcoming in The Italian Academies 1525-1700: Networks of Culture, Innovation and Dissent, ed. by Jane E. Everson, Denis V. Reidy and Lisa Sampson (Oxford: Legenda).

19. Giovanni Calendoli, 'Le Compagnie della Calza, Ruzante e la compagnia Padovana del 1545', in Il convegno internazionale di studi sul Ruzante, ed. by Giovanni Calendoli and Giuseppe Vellucci (Venice: Corbo e Fiore, 1989), pp. 325-31 (pp. 326-29).

20. On the seasonal and repetitive nature of arte performances, see Anne MacNeil, Music and Women of the 'Commedia dell'Arte' in the Late Sixteenth Century (Oxford: Oxford University Press, 2003), p. 5 n. 10, p. 8 n. 13.

21. On the Bavaria performance, see Nino Pirrotta and Elena Povoledo, Music and Theatre from Poliziano to Monteverdi, trans. by Karen Eales (Cambridge: Cambridge University Press, 1982), pp. 108-11. For seventeenthcentury amateur improvised comedy, see Luciano Mariti, Commedia ridicolosa: comici di professione, dilettanti, editoria teatrale nel Seicento, storia e testi (Rome: Bulzoni, 1979); and Elena Tamburini, 'Comici, cantanti e letterati nell'Accademia Romana degli Umoristi', Studi Secenteschi, 50 (2009), 89-112. For the Intronati's imitation of comic masks in their games (veglie) as opposed to their dramaturgical techniques, see Riccò, $L a$ 'miniera' accademica, pp. 130-39.

22. The same is true of plays performed by the Accademia Fiorentina (Zanré, Cultural Non-Conformity, p. 150), and for court performances of Guarini's Pastor fido in the 1580s-90s, see Lisa Sampson, Pastoral Drama in Early Modern Italy: The Making of a New Genre (Oxford: Legenda, 2006), pp. 179-81.

23. Alessandro Marcigliano, 'Giovan Battista Verato: un attore nella Ferrara del Cinquecento', in Scenery, Set and Staging in the Italian Renaissance: Studies in the Practice of Theatre, ed. by Christopher Cairns (Lewiston, NY: Edwin Mellen, 1996), pp. 81-99. See above, n. 9.

24. Calendoli, 'Le Compagnie della Calza', pp. 328-30.

25. On Venetian theatre legislation, see Eugene J. Johnson, 'The Short, Lascivious Lives of Two Venetian Theaters, 1580-85', Renaissance Quarterly, 55.3 (2002), 936-68 (pp. 939-44, 946-57). For the actors of the Vicenza performance, see Mazzoni, L'Olimpico, pp. 141-48. The Olimpici in 1605 may even have dropped a planned performance of Guarini's Idropica with a professional company (the Gelosi?) because of the scandal it would cause, ibid., pp. 64-69.

26. Alberto Gallo, La prima rappresentazione al Teatro Olimpico, con i progetti e le relazioni dei contemporanei, preface by Lionello Puppi (Milan: Il Polifilo, 1973), pp. 33-37 (Letter by Giacomo Dolfin to Battista Guarini, Venice, 9 March 1585); pp. 39-51 (Letter from Antonio Riccoboni to Benedetto Zorzi, Podestà of Vicenza, Padua, post 3 March 1585) (pp. 35, 49, 50). See also Mazzoni, L'Olimpico, pp. 87-207.

27. Dolfin, in Gallo, ibid., p. 35. On the Pellizzari sisters (and for Maddalena Casulana below), see Iain Fenlon, Music and Patronage in Sixteenth-Century Mantua, 2 vols (Cambridge: Cambridge University Press, 1980), i, 127-28; also the praise by Maddalena Campiglia, Flori: A Pastoral Play [1588], ed. by Virginia Cox and Lisa Sampson, trans. by Virginia Cox (Chicago, IL: Chicago University Press, 2004), III.6, p. 183, p. 320 n. 74.

28. See Virginia Cox, 'Members, Muses, Mascots: Women and Italian Academies', forthcoming in Everson et al. (eds), The Italian Academies 1525-1700; for the podcast of the paper delivered at the conference on 'The Italian Academies, 1525-1700: The First Intellectual Networks of Early Modern Europe', 17 September 2012, British Library, London, see <http://backdoorbroadcasting.net/2012/09/virginia-cox-members-muses-mascotswomen-and-italian-academies/>. Cox explores fourteen cases of academy membership for women between 1543 and 1650, and other kinds of association by women with academies 'beyond membership'. See also her The Prodigious Muse: Women's Writing in Counter-Reformation Italy (Baltimore, MD: Johns Hopkins University Press, 
2011), esp. pp. 13, 15-19, 95-96, 233-34. For Sarocchi, see also Tamburini, 'Comici, cantanti e letterati', pp. 96, 105.

29. Henke, Performance and Literature, pp. 85-105; Siro Ferrone, 'La Commedia dell'Arte senza commedia', Biblioteca teatrale, 3 (2011), 163-74.

30. Siro Ferrone, 'Introduzione' to Commedie dell'Arte, 2 vols (Milan: Mursia, 1985), i, 5-69; and Attori mercanti corsari: la Commedia dell'Arte in Europa tra Cinque e Seicento (Turin: Einaudi, 1993), pp. 203-24.

31. Tessari, La Commedia dell'artecento, p. 57; MacNeil, Music and Women, p. 1.

32. Andrews, Scripts, pp. 91-92, 100-07.

33. Mazzoni, L'Olimpico, pp. 145-47.

34. Il Verato Secondo ovvero Replica dell'Attizzato Accademico Ferrarese in difesa del Pastor fido... [1593], in Delle Opere del Cavalier Battista Guarini, 4 vols (Verona: Tumermani, 1738), iii, 1-384 (pp. 29-31, 44-47). On this episode, see Pieri, ' "Il Pastor fido"', pp. 4-9.

35. Tamburini, 'Comici, cantanti'.

36. Antonio Maria Spelta, Historia ... De' fatti notabili occorsi nell'universo, \& in particolare del Regno de' Gothi, de' Longobardi, de i Duchi di Milano, [...] Con una nuova aggiunta (Pavia: Pietro Bartoli, 1602), 'Aggiunta', p. 170. On Andreini's academic name and emblem, see Ferdinando Taviani, ' "Bella d'Asia": Torquato Tasso, gli attori e l'immortalità', Paragone letteratura, 35 (1984), 3-76 (p. 5). For a reference to the actress's association with another Pavia academy, the Affidati, but without further supporting documentation, see, ed., 'Sul Tesin piantāro laureti': poesia e vita letteraria nella Lombardia spagnola (1535-1706), Simone Albonico (Pavia: Cardano, 2002), pp. 22, 188. On Isabella Andreini's two volumes of Rime, see ibid., pp. 312-18, and esp. Chiara Cedrati, 'Isabella Andreini: La vicenda editoriale delle "Rime" ', ACME - Annali della Facoltà di Lettere e Filosofia dell'Università degli Studi di Milano, 60.2 (May-August 2007), 115-42 <http://www.ledonline.it/acme/allegati/Acme-07-II-05Cedrati.pdf> [accessed 19 March 2013]; and Anne MacNeil, 'Introduction' to Selected Poems of Isabella Andreini, ed. by Anne MacNeil, trans. by James Wyatt Cook (Lanham, MD: Scarecrow Press, 2005), pp. 1-28. See also Lisa Sampson, '“Gir' in porto a le degn'opre Intenta": Isabella Andreini and the Intenti Academy of Pavia' (2014), podcast on <http://www.casaitaliananyu.org/content/isabella-andreini-and-intenti-academy-pavia-2014>.

37. Fiaschini, L'Incessabil agitazione', pp. 15-16, 21-49.

38. Stefano Mazzoni, 'Genealogia e vicende della famiglia Andreini', in Origini della Commedia Improvvisa o dell'Arte, ed. by M. Chiabò and F. Doglio (Rome: Torre d’Orfeo, 1996), pp. 107-61 (p. 130). For Giovan Battista's La venetiana (two editions 1619), published with the pseudo-academic name Sier Cocalin dei Cocalini da Torzelo Academico Vizilante ditto el Dornioto, see Ferrone, Attori mercanti corsari, pp. 205, 211-12. For the Venetian Accademia dei Vigilanti (recorded from 1602), see Maylender, v, 459-62.

39. La Fillide, fauola pastorale, dell'Acceso Academico Rinouato (Ferrara: Vittorio Baldini, 1579). See the caustic comment by the printer of a later edition on the importance of establishing legitimate authorship, in Camillo Della Valle, Fillide, egloga pastorale (Ferrara: Vittorio Baldini, 1584), Dedicatory letter, fols A2v-A3r. On Bernardino Lombardi (of the Confidenti or Uniti troupe), author of a comedy L'Alchemista (Ferrara, 1583) and a known plagiarist, see Commedie dell'Arte, ed. by Siro Ferrone, 2 vols (Milan: Mursia, 1985), i, 15, 16, 18, 73-74; and Teresa Megale 'Lombardi, Bernardino', DBI, 65 (2005), <http://www.treccani.it/enciclopedia/bernardinolombardi_(Dizionario-Biografico)/> [accessed 2 April 2013].

40. Tamburini, 'Commedia dell'Arte', pp. 26-29; and her 'I comici Gelosi e l'Accademia della Val di Blenio', Teatro e storia, 3 (2011), 175-96. On Borgogni, his multiple academy membership and his close involvement with Andreini, see Kathryn Bosi, 'Accolades for an Actress: On Some Literary and Musical Tributes for Isabella Andreini', Recercare, 15 (2003), 73-117; and Taviani, ' "Bella d'Asia” ', passim; also Sul Tesin, ed. by Albonico, pp. $20,21,110-11$.

41. Cesare Rao, 'L'Accademia de' Zanni a voi Accademici gnoranti desidera salute, e perpetua felicità', in L'Argute et facete lettere [...] nelle quali si contengono molti leggiadri Motti, \& solazzevoli Discorsi (Vicenza: Appresso Perin Libraro, \& Giorgio Greco compagni, 1585), fols 59v-61v, see also fols 33r-45r. On Rao's performance-oriented letters on the model of Andrea Calmo (reprinted at least fifteen times by 1622), and those of other professional comici like Vincenzo Belando, see Ferrone, Commedie dell'Arte, i, 19-20; Marotti and Romei, La commedia dell'arte, ii, 97-104.

42. Rao, L'Argute et facete lettere, fols 59v (Doni reference), 46v-48v, 111r-113r. On the evidence for the Accademia Pellegrini, which revolves solely around Doni and the printer Francesco Marcolini, see Giorgio Masi, 'Coreografie doniane: L'Accademia Pellegrina', in Cinquecento capriccioso e irregolare: eresie letterarie nell'Italia del classicismo, ed. by Paolo Procaccioli and Angelo Romano (Rome: Vecchiarelli, 1999), pp. 45-85 (p. 70). Giuseppe Crimi, 'Appunti per il testo e il commento delle Lettere di Cesare Rao', in Dissonanze concordi: temi, questioni e personaggi intorno ad Anton Francesco Doni, ed. Giovanna Rizzarelli (Bologna: Il Mulino, 2013), pp. 353-74.

43. Cited in Pandolfi, La commedia dell'arte, ii, 20-22; for Belando's fears of linguistic criticism of his comedy (Gli amorosi inganni, 1609) by 'colonies of academicians', like that of the Crusca for Tasso's epic, see pp. 162-63.

44. Il Trionfo di Scappino parte prima: di Bartolomeo Bocchini detto Zan Muzzina... (Modena: Bartolomeo Soliani, 1655) and Del Trionfo di Scappino e della Zagnara Di Zan Muzzina Parte seconda, cited in Pandolfi, La commedia dell'arte, iv, 191-92.

45. Oratione d'Adriano Valerini Veronese, In morte della Divina Signora Vincenza Armani, Comica Eccellentissima. Et alcune rime dell'Istesso e d'altri Auttori, in lode della medesima. Con alquante leggiadre e belle Compositioni di detta Signora Vincenza (Verona: Per Bastian dalle Donne, \& Giovanni Fratelli, n.d. [1570?]), fol. 7v. Valerini's oration without the verse is transcribed in Marotti and Romei, eds, La commedia dell'arte, ii, 31-41; on Valerini, see pp. 27-30. 
46. Valerini, Oratione, fols 17v, 20v-21r, 31r-v, 35r-v; Riccò, La 'miniera' accademica, pp. 131, 142-43, 147-52, 155-64; see also Tessari, La Commedia dell'arte, p. 56.

47. Archivio di Stato, Verona, Summario degli atti, Fondo Dionisio-Piomarta, ms 634 [henceforth Summario], 13 April 1583 c. 58 t.o (folios not numbered in sequence). For the possibility that this manuscript copy may correspond with that of Asinari's tragedy in Valerini's hand sent to the Filarmonici, as registered in the 1734 index of books of Giulio Saibante, see Adriano Valerini, Le bellezze di Verona, ed. by G. P. Marchi (Verona: Stamperia Valdonega, 1974), pp. xxvii-xxviii.

48. Ferrone, Commedie dell'arte, i, 73-76.

49. Valerini, Le bellezze, ed. by G. P. Marchi, pp. xxxiii, 97-98.

50. On continuing ambiguous attitudes of Italian actors engaged in literary activities towards their practical art even in the later seventeenth century, see Tessari, La commedia dell'arte, pp. 61-62.

51. Summario (for performances of Alceo see entry 15 May 1585). A manuscript inventory of the academy from this year also shows they had a theatrical stage set and properties, see G. Turrini, L'Accademia Filarmonica di Verona dalla fondazione (Maggio 1543) al 1600 e il suo patrimonio musicale antico (Verona: Tipografica Veronese, 1941), p. 186; Paolo Rigoli, 'L'architettura effimera: feste, teatri, apparati decorative', in L'architettura a Verona nell'età della Serenissima (sec. XV-sec. XVIII), ed. by Pierpaolo Brugnoli and Arturo Sandrini, 2 vols (Verona: Banca popolare di Verona, 1988), i, 1-86, 391-414 (p. 55).

52. See Marco Di Pasquale, 'Intorno al patronato della musica della Accademia Filarmonica di Verona nel Cinquecento: riflessioni e congetture', Recercare, 23.1-2 (2011), 35-63. On the role of the Brusasorzi and more generally on theatre in Verona, see my forthcoming 'Gentlemen of Verona: Theatre in the Accademia Filarmonica, 1543-1608'.

53. Bosi, 'Accolades', pp. 87-89; G. P. Marchi, 'L'esperienza teatrale di Adriano Valerini', in La commedia dell'arte tra Cinque e Seicento in Francia e in Europa. Atti del Convegno Internazionale di Studio, Verona-Vicenza, 19-21 Oct. 1995, ed. by Elio Mosele (Fasano: Schena, 1997), pp. 173-80 (pp. 173-74).

54. Isabella Andreini, Mirtilla (Verona: Girolamo Discepolo, 1588; and Sebastiano dalle Donne and Camillo Franceschini, 1588); La Mirtilla. Fauola pastorale ... Di nuouo dall'istessa riueduta, et in molti luoghi abbellita (Verona: per Francesco dalle Donne, \& Scipione Vargnano suo genero, 1599).

55. ASVer, Archivio Dionisi-Piomarta, ms 637 [unpaginated], Rime dedicated to Alberto Lavezzola [1590?]. This fair copy codex in many hands includes verse by Filarmonici academicians using their nicknames, and by (named) dramatists, who were not members: Giovanni Fratta, Luigi Groto d'Adria, Vincenzo Giusti as well as Valerini himself. On the manuscript, see Marco Materassi, Il Primo Lauro. Madrigali in onore di Laura Peperara. Ms 220 dell'Accademia Filarmonica di Verona [1580] (Treviso: Diastema Fiori Musicali, 1999), p. VII [available on <http://web.tiscali.it/ensemble900/Diastema/Libri/Schede/Materassi.pdf>]. Cf. the 'secret' evidence of relations between Intronati and professional practitioners in Riccò, La 'miniera' accademica, p. 141. My thanks to Martin McLaughlin and Nicola Gardini for their assistance in translating the sonnet for Valerini.

56. Adriano Valerini, Rime diverse et origine della famiglia della famiglia Bevilacqua (Verona: per Sebastiano dalle Donne e fratelli, [1577]), edition held in the Archive of the Accademia Filarmonica, Verona, Coll. 202. For a 1628 inventory of the library holdings, see Turrini, L'Accademia Filarmonica, p. 195. On Bevilacqua, see Bosi, 'Accolades', pp. 84-91.

57. Marchi, 'L'esperienza teatrale', p. 175. 58. Archivio dell'Accademia Filarmonica, Verona, Atti, b. 41, fol. 8r.

59. On this episode, see Bosi, 'Accolades', pp. 91-95. The verse was indeed printed under the Academy's name in Isabella Andreini's Rime (Milan: Appresso Girolamo Bordone, \& Pietromartire Locarni, 1605), Part 2, p. 28.

60. For Andreini's networks, see Bosi, 'Accolades', pp. 102-04; Fiaschini, L'Incessabil agitazione', pp. 17, 55-62. For Isabella Andreini and the Gelosi's performances in Milan, see the chronology in Macneil, Women and Music, pp. 187-263; Roberta Giovanna Arcaini, 'I comici dell'arte a Milano: accoglienza, sospetti, riconoscimenti', in La scena della Gloria: drammaturgia e spettacolo a Milano in età spagnola, ed. by A. Cascetta and R. Carpani (Milan: Vita e pensiero, 1995), pp. 268-76. For the importance of Pavia academies in poetic production, see Sul Tesin, ed. by Albonico, pp. 18-19, 21, 27, and the various entries on verse publications.

61. Macneil, Music and Women, pp. 2, 250-51, 285; on the Rime of 1601, see Cedrati, 'Isabella Andreini', pp. 116-28; Sul Tesin, ed. by Albonico, pp. 312-15.

62. On the Intenti, see Siro Comi, Ricerche storiche sull'accademia degli Affidati e su altri analoghi stabilimenti in Pavia (Pavia: Comino, 1792), pp. 47-58; now in a modern edition with manuscript revisions by Comi, in Maria Cristina Regali, 'Le ricerche storiche sull'Accademia degli Affidati di Siro Comi: edizione delle postille dell'autore' (Como: Litografia New Press, 1999), pp. 218-24; see also, based on Comi, Maylender's entry (iii, 319-23). On membership, see Fiaschini, L'Incessabil agitazione', pp. 55-62.

63. For Andreini's whereabouts, see Macneil, Music and Women, pp. 250-56. For Andreini's performance and verse for her, as Accademica Intenta, see Spelta, Aggionta, pp. 169, 172. See also the somewhat ambiguous admiration for her eloquence by the Flemish university professor and Intenti member Erycius Puteanus, in Macneil, ibid., pp. 305-23 (esp. 311).

64. Taviani, 'Bella d'Asia', pp. 25, 27-29. For Archilei, see Macneil, Music and Women, p. 21.

65. Isabella Cervoni (before 1599) and Ippolita Benigni (by 1609) belonged to the Affidati. In the 1550s, the poet Alda Lunato Torelli served the Affidati as a cultural muse and figurehead, see Cox, The Prodigious Muse, pp. 13, 15; Virginia Cox, Women's Writing in Italy, 1400-1650 (Baltimore, MD: Johns Hopkins University Press, 2008), pp. 102-03, 306 n.106; Sul tesin, ed. by Albonico, pp. 148-50.

66. Comi, Ricerche storiche, ed. by Regali, p. 224. 
67. Cedrati, 'Isabella Andreini', pp. 123, 124-25, 127-29, 136-39, 141.

68. Andreini, Rime, 1605, dedicatory letter by the printers to Margherita Casati, which mentions performances by Isabella for her and other Milanese ladies (fol. A2v).

69. Fiaschini, L'Incessabil agitazione', pp. 12-13, 15-16, 21-49. The following discussion draws on this source.

70. See Andreini, La Saggia Egiziana: dialogo spettante alla lode dell'arte scenica (Florence: Volcmar Timan, 1604), dedication to Don Antonio de' Medici.

71. Fiaschini, L'Incessabil agitazione', p. 15. Andreini's first publications are connected in various ways with the Spensierati Academy: his dialogue on theatre, La Saggia Egiziana, recalls in the dedicatory letter the academy's contribution of verse to his 1604 edition of Florinda; his religious poem Divina Visione in soggetto del beato Carlo Borromeo (poemetto) (Florence: Volcmar Timan, 1604) is dedicated to the academy (23 Dec. 1604); academy members contributed to the verse added to his Florinda, tragedia (Milan: Bordoni, 1606), pp. 5-11 (British Library copy consulted, shelf-mark C.73.c.10); and see the 'poemetto' Pianto d'Apollo, Rime funebri in morte d'Isabella Andrini Comica Gelosa ... (Milan: Bordoni e Locarni, 1606). For a complete list of Giovan Battista Andreini's publications, see Comici dell'Arte: corrispondenze, ed. by Siro Ferrone (Florence: Le Lettere, 1993), i, 71-75. No correspondence relating to this early period of Andreini's career, or his links with the Spensierati appears in this volume. On the connections between Virginia Ramponi Andreini (Florinda) and the Spensierati, including their Rime in lode della signora Verginia Ramponi Andreini, comica Fedele, detta Florinda (Florence: Volcmar Timan, 1604), see Emily Wilbourne, ' "Isabella ringiovinita": Virginia Ramponi Andreini before Arianna', Recercare, 19.1-2 (2007), 54-67; and on academic verse for Virginia esp. in the Raccolta Morbio, I, Milan, Biblioteca Braidense, Milan, see Wilbourne, 'La Florinda: The Performance of Virginia Ramponi Andreini' (unpublished PhD dissertation, New York University, 2009),pp. 185-216; 221-24.

72. Tamburini, 'Comici, cantanti e letterati'. Mariti, Commedia ridicolosa.

73. Mazzoni, 'Lo spettacolo', pp. 888, 891; Tessari, La commedia dell'arte, pp. 62-63 (Barbieri citation).

74. '[Frittellino (i.e. Cecchini) vuole] inviarsi a Roma, et colà porre un accademietta in piedi e alcuna volta privata', Letter from Giovan Battista, Turin, to Duke Vincenzo Gonzaga, Mantua, 14 August 1609, in Comici dell'Arte: corrispondenze, i, 91.

75. Tessari, La commedia dell'arte, pp. 56-68.

76. Giovan Battista Andreini, Le due commedie in commedia, in Commedie dell'Arte, ed. by Siro Ferrone, ii, 17-105; iv.1, p. 66; iv.2, p. 68 (Fabio's nickname). On Virginia Ramponi Andreini, see above n. 71. 